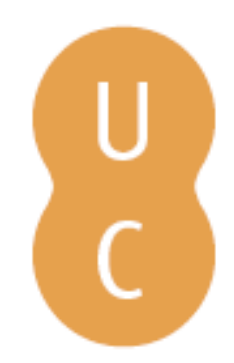

\title{
nombalina
}

Ciam's Ghosts: Le Corbusier, art, and world war II

Autor(es): $\quad$ von Moos, Stanislaus

Publicado por: Imprensa da Universidade de Coimbra

URL

persistente: $\quad$ URI:http://hdl.handle.net/10316.2/41611

DOI: $\quad$ DOl:https://doi.org/10.14195/978-989-26-1338-3_8

Accessed : $\quad$ 26-Apr-2023 07:29:34

A navegação consulta e descarregamento dos títulos inseridos nas Bibliotecas Digitais UC Digitalis, UC Pombalina e UC Impactum, pressupõem a aceitação plena e sem reservas dos Termos e Condições de Uso destas Bibliotecas Digitais, disponíveis em https://digitalis.uc.pt/pt-pt/termos.

Conforme exposto nos referidos Termos e Condições de Uso, o descarregamento de títulos de acesso restrito requer uma licença válida de autorização devendo o utilizador aceder ao(s) documento(s) a partir de um endereço de IP da instituição detentora da supramencionada licença.

Ao utilizador é apenas permitido o descarregamento para uso pessoal, pelo que o emprego do(s) título(s) descarregado(s) para outro fim, designadamente comercial, carece de autorização do respetivo autor ou editor da obra.

Na medida em que todas as obras da UC Digitalis se encontram protegidas pelo Código do Direito de Autor e Direitos Conexos e demais legislação aplicável, toda a cópia, parcial ou total, deste documento, nos casos em que é legalmente admitida, deverá conter ou fazer-se acompanhar por este aviso.

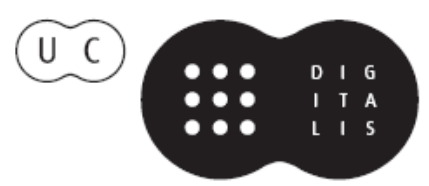


Ivan Zaknic

Arthur Rüegg

David Leatherbarrow

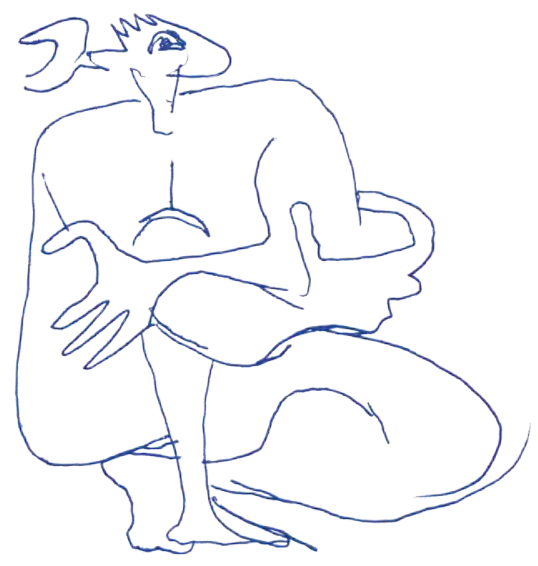

Christoph Schnoor

Francesco Passanti

Johan Linton

Stanislaus von Moos

Maria Candela Suárez

\section{Le Gorbusier}

\section{HISTORY TRADITION}

Edited by

Armando Rabaça 


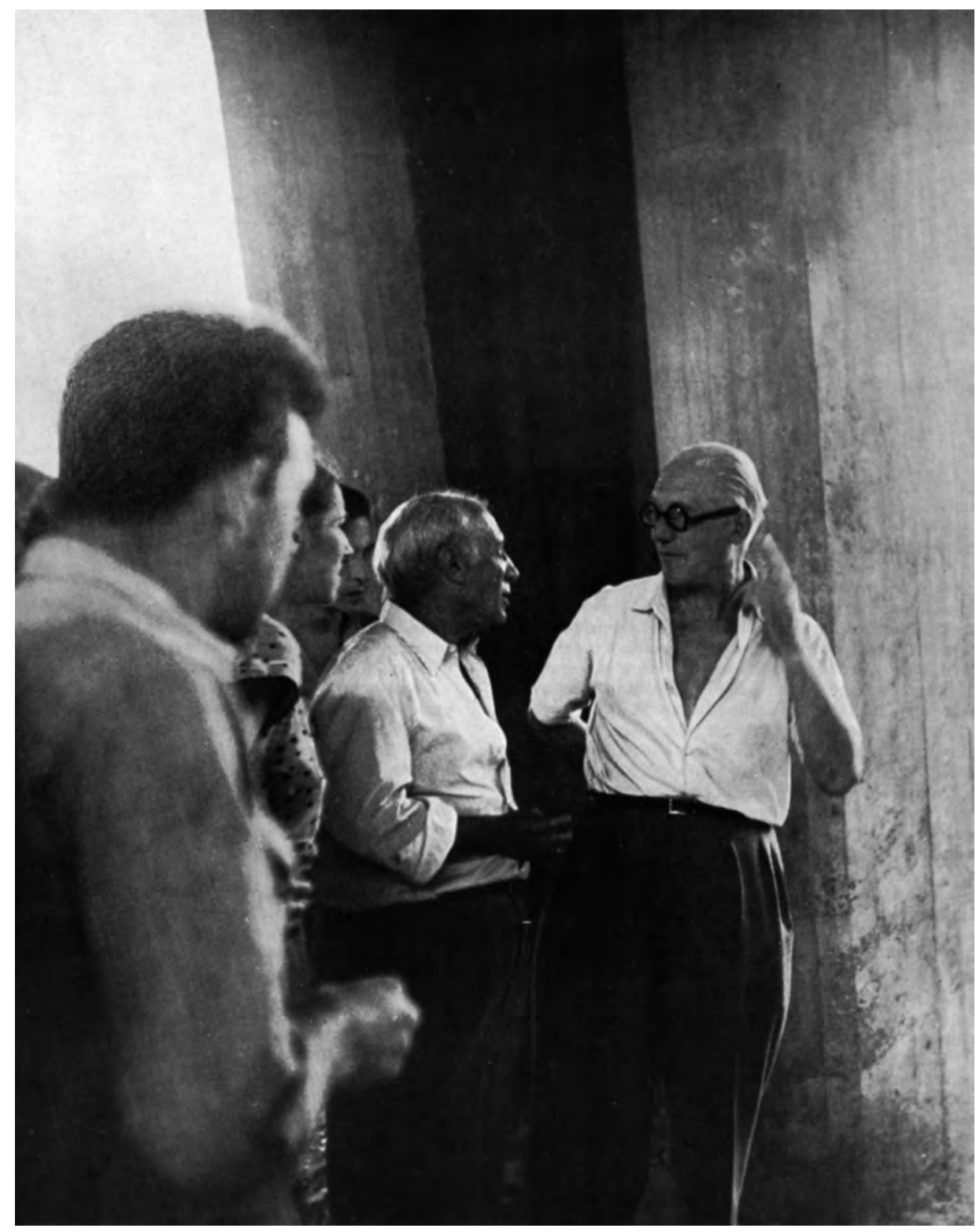

1. Picasso visits the construction site of the Unité d'habitation in Marseilles (October 1949).

Frontispiece of Le Corbusier, Euvre Complète, 1946-1952. 


\section{Cinm's Ghosts}

\section{Le Corbusier, Art, And World War iI}

\section{Meeting Picasso}

The Unité d'habitation in Marseilles is Le Corbusier's most ideologically charged, socially ambitious and politically controversial project of the postwar years (1947-1952). ${ }^{1}$ As to its aimed for rank in the history of art, we need only to look at the snapshot that shows the architect together with Picasso visiting the construction site. The picture was taken in October, 1949: it shows Picasso, occupying the middle of the picture; his regal profile stands out in the sunshine against the murky background of a piloti. Around him is a gathering of architects, all ready to accept the blessing - and the stigmataof modern art. Le Corbusier, behind the mask of his horn-rimmed glasses, stands clumsily to the side, sharply observed by his collaborators (among them Bernhard Hoesli clearly recognizable on the far left), all eager to see if, and with what arguments, their boss will pass the test in the eyes of the artist regarded as the unequalled master of modern art.

Picasso had been Le Corbusier's supreme point of reference in matters of art since the days of L'Esprit Nouveau. In 1939, ten years before the Marseilles encounter, the painter had entrusted Guernica, the mural shown in the Pavilion of the Spanish Republic at the 1937 Paris World's Fair, to the Museum of Modern Art in New York for safekeeping. Meanwhile, with the monumental outcry against the savagery of Nazi air raids still resonating in New York, 
his aura had reached a peak in the world of art and politics. After all, MomA was universally seen as Modern Art's unquestioned hub, not to mention the fact that Picasso was a membership of the French Communist party, which added a further element to the magic of his name in a way that clearly outshone the ambivalences of Le Corbusier's own chequered political past. ${ }^{2}$ It is therefore understandable that Le Corbusier reproduced the picture as the frontispiece of the fifth volume of his Euvre complète. Picasso's visit to the Unite appeared like the art world's accreditation of his own efforts as an artist-architect (Fig. 1). ${ }^{3}$

However, if Picasso does not always appear in person, as in Marseilles, his presence is ubiquitous in Le Corbusier's work after 1937, the year of Guernica. There is a photograph of the model of the Ronchamp chapel, for example, in front of a large painting whose date and subject matter bears no direct connection with it, except for the Art Nouveau rhythm of sweeping outlines that reverberate with the model's curves (Fig. 2). ${ }^{4}$ The painting in question, La Menace, dates from 1938 and the scene depicted is martial. A tall nude woman is standing to one side, only just identified by her hip, leg, and navel. A much shorter man on the right (a maréchal ferrant or "farrier" a horse, which clearly dominates the scene, its head and mane intersecting with the woman's face. The distressed expression of the "Amazon" and her brown face, turned to the right, are nearly eclipsed by the grimace of the horse's head above her. With its eyes wide open and nostrils flared, its ears pricked and tense, and teeth bared, the horse dramatizes the pain and panic that is in the air; it is an allegory of despair. A glance at Guernica (and at Picasso's studies for the painting) is enough to contextualize La Menace within contemporary art (Fig. 3). ${ }^{6}$

A letter dated March 6, 1938 and addressed to Le Corbusier's mother, casts further light on the painting and suggests a direct connection with Guernica. In it, the architect refers to the "disquietudes of the times," which forced him to work on La Menace from early in the morning and deprived him of the "beautiful tranquillity of the postwar years" (he is referring, of course, to the Platonic dreams of Purism after 1918). The "terrifying risks 

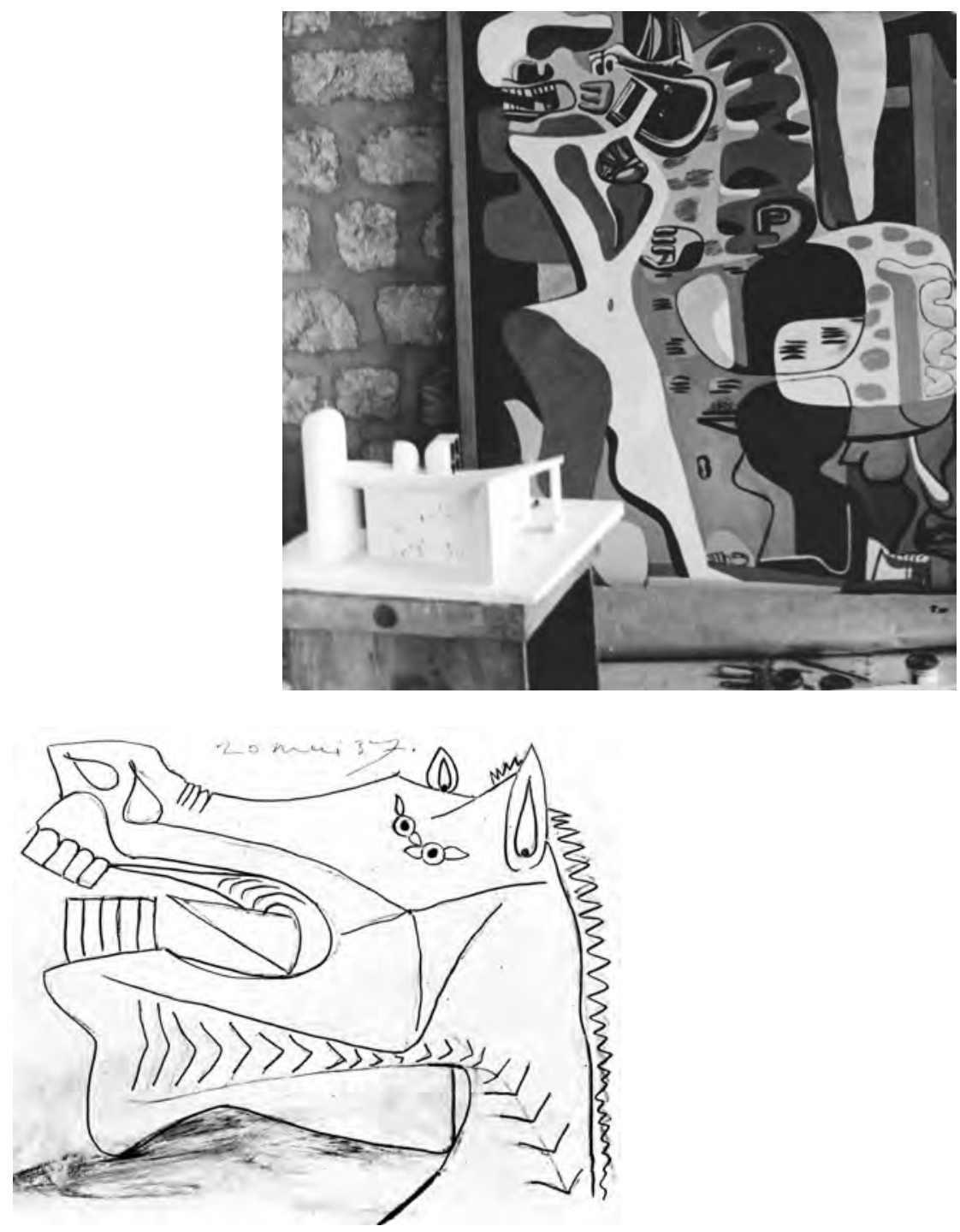

2. Model of the Ronchamp chapel (built between 1951 and 55) in front of La menace, a painting of 1938. Unidentified photographer.

3. Pablo Picasso.

Head of wounded horse.

Sketch study for the painting shown at the pavilion of the Spanish Republic at the 1937 Paris World's Fair (Guernica).

From Cahiers d'Art, 1937. 
of a nameless war" are in the air, he says, although he does not rule out that "this terrible fever, this agony" may well prove to be "the end of the malady," bringing about "the delivery of a new civilization." The Spanish Civil War appears to have played a key role in this "disquietude." In the year following the painting of La Menace, Franco's brutal conquest of Barcelona, an event that forced many of Le Corbusier's republican friends to leave the country (José Luis Sert, among others), would be at the core of yet another series of allegorical paintings. ${ }^{8}$

Le Corbusier's interwar tribulations as a "fellow traveller" of French fascist groups and, more generally, of France's "droite autoritaire," has recently become a subject of intense interest. ${ }^{9}$ While privately (and not so privately) committed to ideas about democracy, capitalism, war, and "la question juive," which puzzled friend and foe alike, ${ }^{10}$ the artist Le Corbusier liked to cast his political instincts in mysterious allegories, not totally unlike his alter ego Picasso in that respect. As an incarnation of archaic man, nestling under the wings of ancient mythology and musing about the law of eternal return, he liked to picture war as a cosmic fatality, or even as a universal, inevitable purgatory rite at the service of man's (and architecture's) rebirth. ${ }^{11}$ It is tempting to consider the mysterious combination of the Ronchamp model with La menace as an illustration of such a mythic practice. Note that, at one point, the architect compares the whitewashed walls of the church to "the Virgin carrying in her womb the martyrdom of her child." ${ }^{2}$ Is the chapel thus presented next to the painting the baby that has been delivered from its mother's womb, or does its form itself incorporate the suffering? Whatever the case, the harmony of the building's outline seems like the counterimage of the agony and bloodshed that preceded its birth. Could it be that Ronchamp, apart from its role as a pilgrimage chapel, needs to be seen as a war memorial ${ }^{13}$

Whereas the message of La menace is mythological and apocalyptic, the often reproduced Graffite à Cap Martin, also of 1938, appears to represent a pastoral scene and to carry a pacifying message. In formal terms, as a monochrome mural, this work, too, recalls Guernica, though not in respect of 


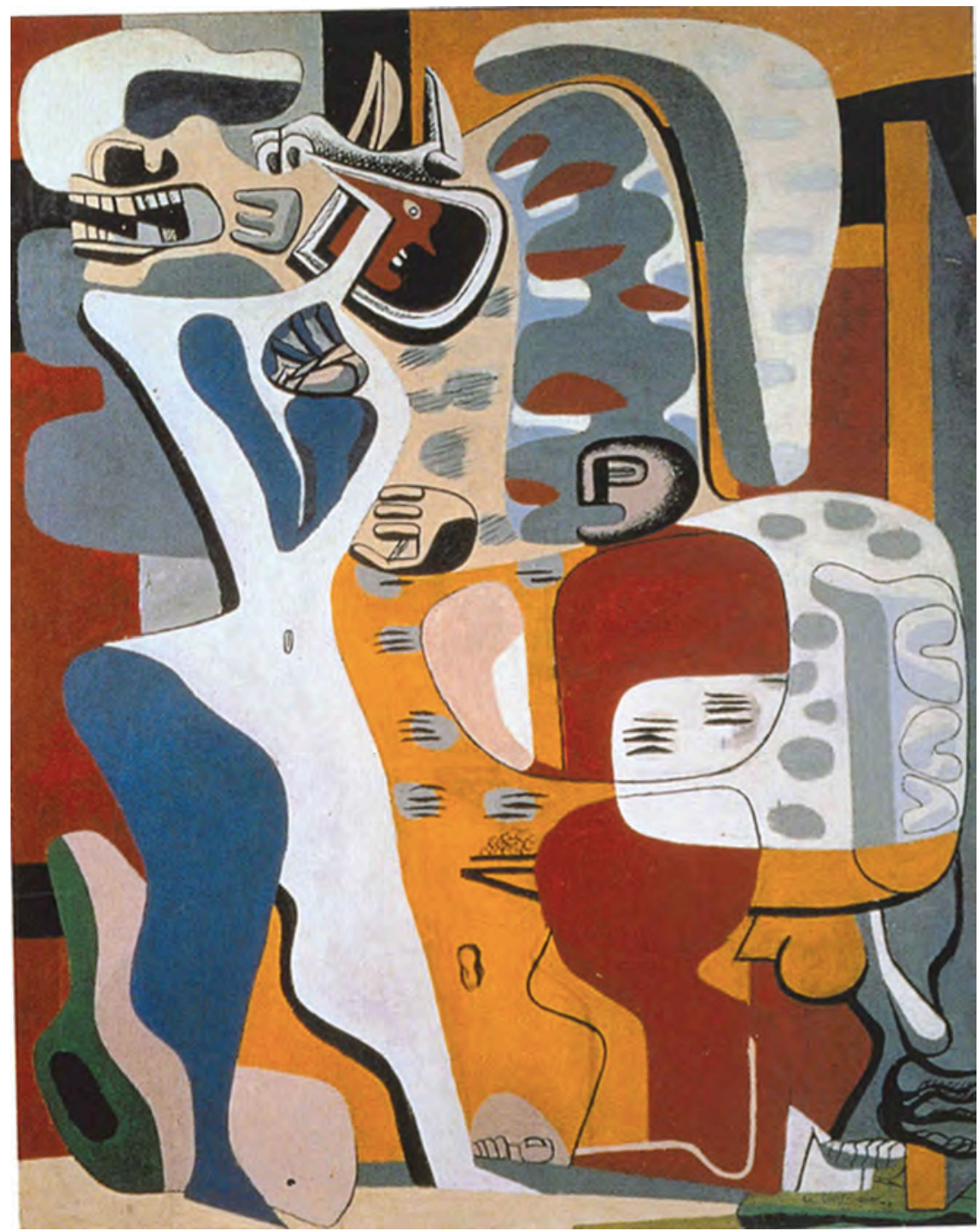

4. Le Corbusier.

La menace.

Oil on canvas, $162 \times 130 \mathrm{~cm}$. 
style and emotional content. The mythology of "Algérie française," which sparked Le Corbusier's interest in Delacroix's Femmes d'Alger to begin with (for that painting doubtlessly served as the basis for the mural), to say nothing of the troubling presence of what looks like a swastika inscribed on one of the figures, rather suggests that what the painter had in mind was a tribute to the pacific and constructive forces of some kind of Mediterranean fascism. ${ }^{14}$ Whether Picasso's own fifteen variations on Delacroix's Femmes d'Alger, executed between 1954 and 55, had anything to do with the architect's work is a matter of speculation. It is interesting that Le Corbusier later claimed to have at one point shown the mural to Picasso. He even recalled that, while examining the mural, Picasso instantly recognized the connection with Delacroix. ${ }^{15}$

Be that as it may, Picasso's symbolic patronage of Le Corbusier's postwar Euvre complète was all the more adroitly staged as it implied both cultural nobilitation and political exorcism. Picasso's public engagement with the cause of the left was a matter of public record in the years after 1945 (he had joined the French Communist party in 1944). Furthermore, his many variations on the theme of the peace dove, multiplied by the thousands on posters, book covers, handouts, ceramic plates, scarves, etc. (Fig. 5), were about to become synonymous with the international peace movement, which had started in Europe as a response to the American-led arms race, and which notoriously had Stalin's blessings (in fact, centre-right Europe suspected the Kominform of being its ideological headquarters). ${ }^{16}$ Picasso had participated in the Congrès Mondial des partisans de la paix (World Congress of Partisans for Peace) only a few months before his visit to the Unité, a meeting that ended in a mass rally attended by half a million peace activists waving home-made versions of Picasso's Dove of Peace at the Parc des Princes Stadium in Paris. As if touched by the wings of glory, the artist stood on the gallery and remarked to his friend and neighbour, Louis Aragon: "Alors quoi? Dis-moi? C'est la gloire?" 17 Le Corbusier did not participate in the event, although he may have witnessed some of it from his apartment situated directly across the street from the stadium. We do not know whether 

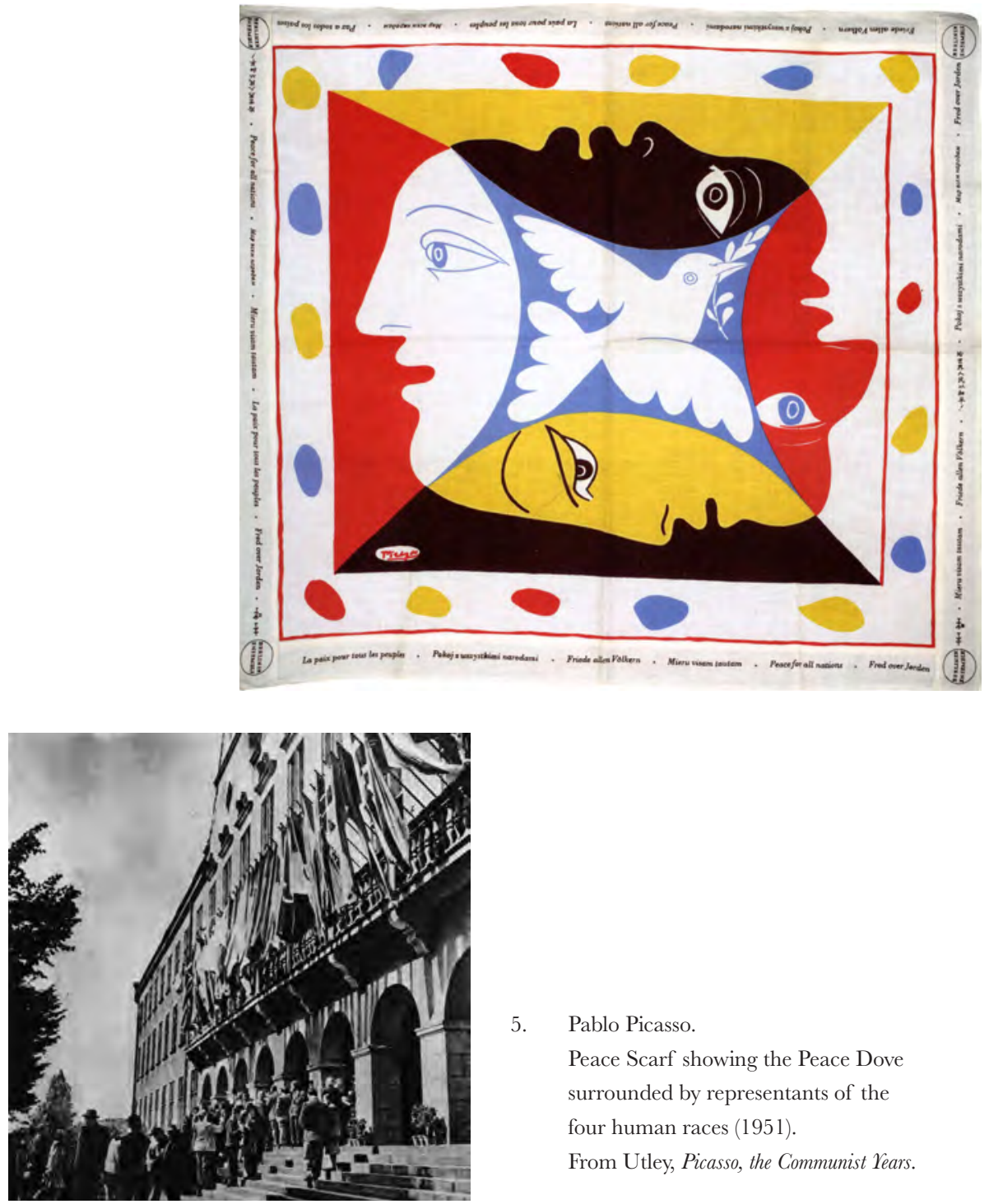

5. Pablo Picasso.

Peace Scarf showing the Peace Dove surrounded by representants of the four human races (1951).

From Utley, Picasso, the Communist Years.

5a. Wroclaw.

Entrance to the Wroclaw Polytechnic School, where the "Congress of the Intellectuals for Peace" was held in 1948.

From Bibrowskiego, Picasso w Polsce (1979). 
he was around at the time. If he was, he may not have felt unalloyed pleasure at seeing Picasso so enthusiastically embraced by the peace-loving masses - a joy he could only dream of one day experiencing himself. In fact, two years later, when visiting Prime Minister Jawaharlal Nehru at his state office in New Delhi, he handed him a copy of the letter he had sent to the Congress in 1949 and in which he had declared his refusal to participate in the event: "They want to place us on the horns of a USA-UssR dilemma. This is the result of a lack of information which can only be obtained by an enquiry on the spot regarding the differences and similarities which condition the fast-developing machinist phenomenon ... (etc.)." ${ }^{18} \mathrm{He}$ had even added a handwritten note saying that in 1948 he had already refused to participate in a similar Congress in Wroclaw. ${ }^{19}$ Le Corbusier must have hoped that the presentation of such an immaculate pedigree as a political "neutralist" would convince Nehru to go ahead with the building of the monument of the "Open Hand," the Non-Alignment Movement's answer to Picasso's Peace Dove (see Fig. 17).

In a letter to ciam Secretary General Giedion, Helena Syrkus, the Polish architect who had just been made vice president of that organization, and who was one of the organizers of the Wroclaw Peace conference, complains bitterly about Le Corbusier's unwillingness to accept the invitation to Wroclaw ("... which for me, as a member of the ciam Council, was a bitter pill to swallow and has given me much food for thought," she added), although she is proud to report that she managed to attract Picasso to the conference instead (Fig. 5a). ${ }^{20}$ Bringing Picasso to Wroclaw hadn't been that easy either, however. What appears to have lured him into accepting was the prospect of travelling to Warsaw by airplane (he had never flown before). Syrkus had asked the pilot to circle Paris a few extra times, and Picasso raved about the "cubist" birds-eye views thus obtained. ${ }^{21}$ In Wroclaw, Picasso proved to be the spearhead among the Western artists, scientists and intellectuals that had accepted the invitation to the conference - people such as Fernand Léger, Paul Eluard, Bertolt Brecht, Eve Curie, Aldous Huxley, and many more. Cordial relationships in "brotherly understanding" were cemented, 
not least with Soviet delegates, Syrkus adds in her note to Giedion. She does not mention Alexander Fadeyev, the president of the Soviet Writers Union, whose keynote speech outraged Picasso. Fadeyev had denounced Picasso's friend Sartre as a "hyena and a jackal," thus encouraging other participants to take the painter aside and "criticize him for the decadent and bourgeois manner of his art." 22

\section{Ciam and "Common Man"}

The Wroclaw congress was in fact symptomatic of the increasing political tension within the world of modernist art in general, even though the divide between "left" and "right" far from followed clear-cut party lines. That the tension was also real within GiAm is highlighted by Helena Syrkus's failure to recruit Le Corbusier to the peace movement. The avant-garde's "problem" with the multifaceted spectrum of left wing "realisms," and in particular with Socialist Realism as the official aesthetic doctrine in the Soviet Union, had been at the core of artistic debates in Europe ever since the mid 1930.s. ${ }^{23}$ By 1947, when ciam planned its first meeting after World War II, which was to be held in Bridgwater, England, it became clear that even as seemingly "a-political" a question as that of the collaboration between artists and architects was enough to reveal a potential mountain of political and cultural discord within the organization. ${ }^{24}$ The autonomy of art with regards to politics could no longer be taken for granted even within cIAm. "Socialist Realism" was no longer taboo.

Weeks before the Bridgwater meeting began, the questionnaire that had been prepared in Zurich as a base for the discussions was picked to pieces by the English MARs Group, which was in charge of the organization: "The aspect of aesthetics that we suggest for discussion at the sixth congress is not the purist approach, but the sociological aspect: the relation of modern architecture with what ordinary people require. ${ }^{.25}$ An alternative questionnaire prepared by the MARs Group raised the issue as to whether architectural design should 
not be based on systematic opinion-polls. Furthermore, the time had come for architects, so it was argued, to pay special attention "to the symbolic or allusive aspect in architecture as opposed to its abstract aesthetic qualities." 26 Finally, some British participants of the congress voted openly in favour of a serious study of the experiences made under "Socialist Realism." James M. Richards himself, one of the organizers of the Bridgwater meeting, complained that in most countries represented at the congress, ciam ideals were couched in a visual language that "the man in the street" was incapable of accepting or even understanding. ${ }^{27}$

As a "neutral" Swiss and through able diplomacy, Giedion, the ciam secretary general, finally managed to prevent a fatal paralysis, if not complete breakdown of the organization. In 1947, he had reviewed James M. Richard's small book Castles on the Ground, a reminder for architects to take seriously ordinary people's expectations with regards to beauty in the built environment (Fig. 6). Perhaps surprisingly, Giedion praised the book as extremely useful. "Richards needs to be praised," so he argues, for not boasting about the robustness of a Swiss architect "who takes it for granted that he is the predestined soul surgeon of the general public." ${ }^{\prime 28}$ Was he thinking of younger compatriots like Max Bill or Alfred Roth, for whom European reconstruction primarily represented an opportunity to finally bring about the victory of pre-war functionalism (Fig. 7)? ${ }^{29}$ Also, Richards does not waste his time "by once again making fun of the English suburbs," Giedion continues. Though incapable of taking seriously these suburban homes as architecture, Richards insists on the seriousness of the "needs that are alive in their inhabitants." ${ }^{\prime 30}$

A friendly salute to Richards, one of the organizers of the Bridgwater meeting, the review was clearly part of an effort on Giedion's part to open a dialogue with the "Marxist" positions on architecture and art that were about to set the tone in Eastern Europe. That Helena Syrkus, the head of the Polish ciam group, was made Vice President of ciam at Bridgwater, points into the same direction. "Following the 2nd World War, new hopes have arisen among the large urban and rural masses," she and her husband, Szymon 
6. J. M. Richards, Castles on the Ground (1946). Cover.

7. A page from Alfred Roth, The New Architecture (1939), showing samples of the buildings documented in the book.
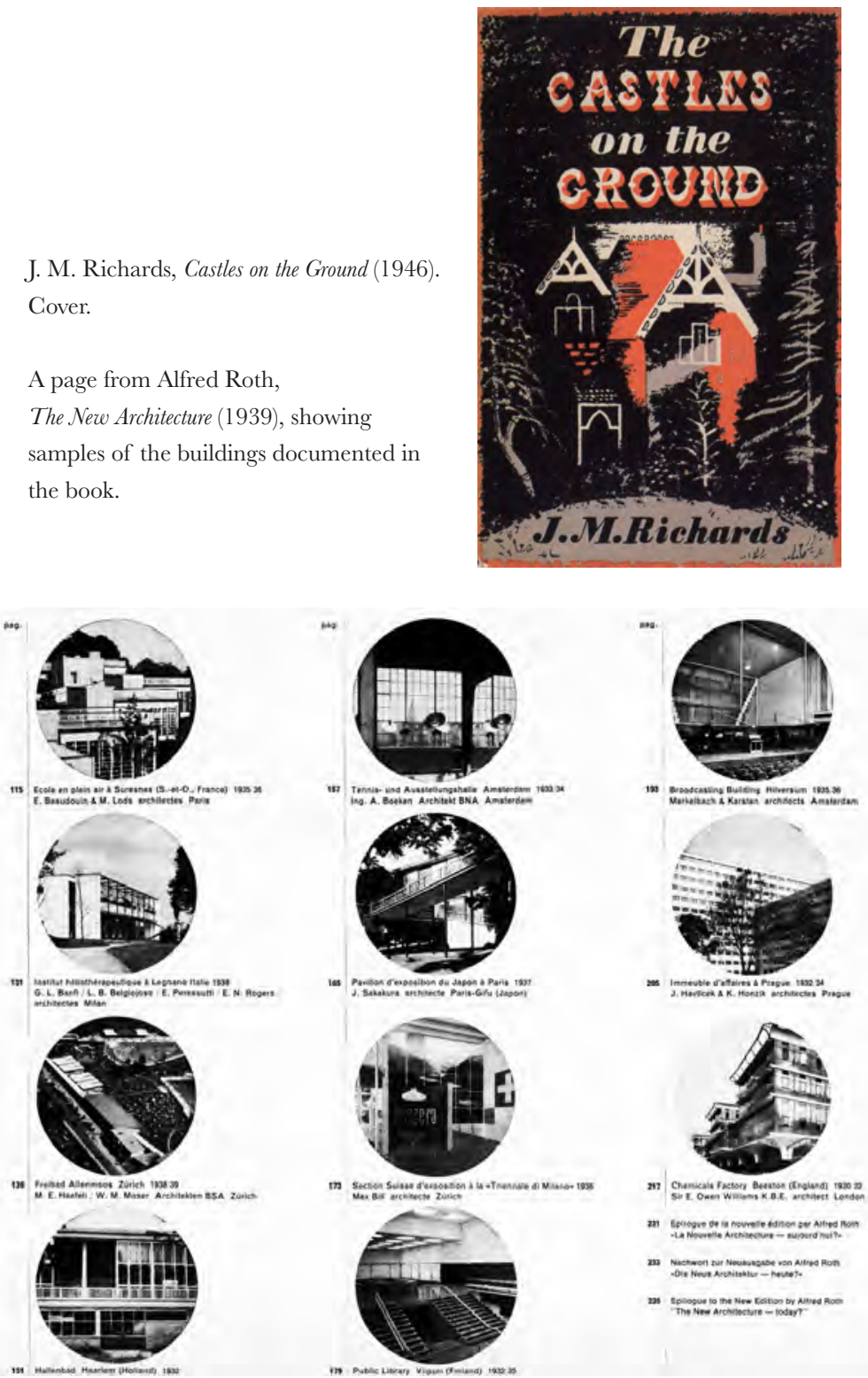
Syrkus, as well as Hans Schmidt and Mart Stam, had written in a declaration previously submitted to the congress: "Their participation in social events took [sic] a greater impetus because the war taught them that through cooperation and social solidarity the material and spiritual progress of the individual is better achieved." 31 The declaration went on to urge ciam to fundamentally revise the role of the architect in the design of man's physical environment, and to drop the term "Modern" from the organization's name: "In concluding the above principles, and while retaining the abbreviated name, the ciam will amend their title," they insisted. "CIAM will from now on be called 'INTERNATIONAL GONGRESSES FOR SOGIAL ARCHITECTURE AND PLANNING." "32

In her subsequent correspondence with Giedion, Syrkus invites the secretary general to open up the organization towards Eastern Europe by choosing Prague or Brno rather than Bergamo as host for the following congress. At one point, she even urges her friend to read Stalin's essay Historical and Dialectical Materialism in order to better understand what architects in Eastern Europe were working on. "What is missing in your extremely interesting book," she writes to her friend, the author of Space, Time and Architecture, "is the the purely Marxist point of view, which you are content to employ emotionally, if one may say so." Why not simply "read in an unbiased way the definition of historical and dialectical materialism given by Stalin?" she writes in the famous essay of 1938. "If you know this work, read it once again carefully, with urbanism on your mind, and you will understand our point of view." 33

With ciam 7 held in Brno or Prague, Syrkus might have succeeded in bringing about the desired shift in CIAm politics. Yet the ciam governing body had decided in favour of Bergamo (Fig. 8). The topical role played by Italian architects in early cIAm history was one of the reasons. That the Democrazia Cristiana, massively aided by the US, had won a landslide victory in Italy's national elections of April 1948, thus preventing the communists from entering the government, made the choice look even more plausible: Italy was now solidly anchored in the Western Block. ${ }^{34}$ Considering the aesthetic 

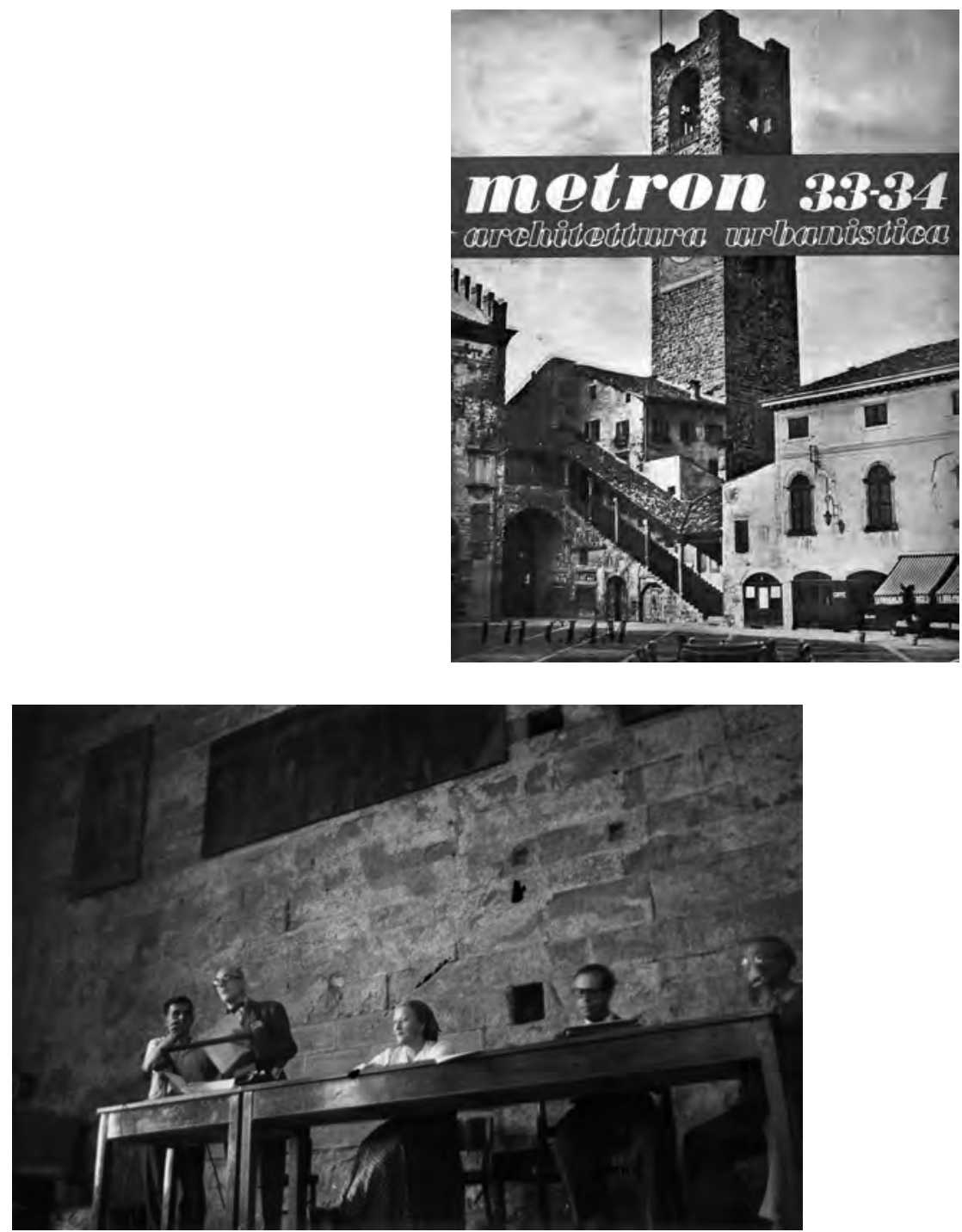

8. Bergamo.

Brolleto (communal palace), where ciam 7 was held. From Metron.

9. Helena Syrkus together with Le Corbusier (left), J. L. Sert and S. Giedion (right) at the 1949 CIAM Congress in Bergamo. 
demands of "common man," Giedion now returned to his older theory of the "ruling taste," which had already helped him to rationalize the crisis of modern architecture in the Soviet Union under Stalin. ${ }^{35}$ According to the secretary general, the situation at the time was characterized by an increasing gap between highly advanced methods of thinking on the one hand and fatal stagnation on the level of emotions on the other. The results were to be seen "in the judgments of politicians of all countries as far as questions of literature, art, and architecture are concerned." Even though their judgment was lagging generations behind, "they nevertheless decide what will be built and what will not be built." ${ }^{36}$ Politics and business continued to press the new into the visual habits of tradition, Giedion lamented. As a result, the paralyzing heritage of 19th century historicism and its culture of historical borrowings had kept official culture under its sway up to that very moment. Was he thinking of Stalin's alleged role in choosing the final project for the Soviet Palace in Moscow between 1933 and 35, which had put an end to the Modern Movement's confidence in Soviet politics? In one of the Bergamo sessions, Giedion evokes a fictive dinner conversation between Truman (the then president of the United States), Stalin, and "a typical fascist": "I believe if one could seat round a table Mr. Truman and a man, who shall be nameless, for Russia, together with a typical fascist, one would find their taste was identical when it comes to passing judgment on this problem of art." ${ }^{\text {37 }}$ In fact, a few moments before, the art historian James J. Sweeney had quoted from a letter Truman had addressed to the American press only two years previously (June 1947):

I do not pretend to be an artist or a judge of art, but I am of the opinion that so-called 'modern art' is merely the vaporing of half-baked lazy people ... There is no art at all in connection with modernism in my opinion. ${ }^{38}$

With the "problem" thus identified as a question of emotional readiness to accept (instead of simply rejecting) the leading role of modern art in organizing visual culture at large, the premises for a discussion on the 
possible roles of tradition and popular taste in art and architecture appeared no longer to exist. As a result, the dialogue with the Modern Movement's Eastern European diaspora appears to have come to a sudden halt when Syrkus (after all, ciam's Vice President) openly challenged what had become the organization's shared notion of cultural politics (see Fig. 9). "We lack a fair attitude towards the people. Art belongs to the people and must be understood by the people," she insisted in her address to the congress. And she added, referring to the splendid 17th century Palazzo Nuovo in which some of the meetings were held: "We of ciam must revise our attitude. The Bauhaus is as far behind us as Scamozzi." 39

Max Bill was first to speak up after Syrkus's presentation. Interestingly, he countered her populist plea with a panegyric of the Unité d'habitation in Marseilles (which, at that moment, was barely two thirds built). Unlike some buildings that are so big they make people feel like "dust," Le Corbusier here reached an exemplary "unité esthétique," Bill argued. Then he went on to use a project by his friend Hans Schmidt as a counter-example. This "house" may be seen as typical for Syrkus's program, according to Bill. It was to contain a mural painting, 20m long, in "popular" style, though clumsily wedged into a small corridor so as to be hardly visible. "The subject has become revolutionary, but the work as such uses an outdated language, it is academic and sterile." 40

Schmidt did not respond. Giedion, in turn, tried to re-focus the conversation towards the "moral" issue of artistic authenticity. Ciam's task, so he insisted, was to defy the "ruling taste" - whether represented by Truman, Stalin, or by any fascist dictator. ${ }^{41}$ It took him time to return to the opposing party's cause, albeit referring to the Bridgwater meeting that had preceded Bergamo. After recalling the question that had been raised by the MARs Group, pondering "how far the ruling taste needs to be taken into account in order to satisfy the needs of the man in the street," he writes: "At the following congress at Bergamo in Italy (1949), the question led immediately to the hottest discussion between East and West, and we felt once more that aesthetic problems are not just personal matters ... but that they are 
a part of our attitude towards the world, and that they merge - sometimes tragically-into politics." ${ }^{42}$ Indeed, consensus within ciam appears to have been close to its breaking point. One year later, Hans Schmidt, after all, one of the founders of CiAm, wrote to his friend Mart Stam in Dresden: "We can no longer afford to sit in ciam and see it being run in such a biased way as is done by Le Corbusier, Giedion, Roth, etc.. We have no choice but to either leave CIAM or to inaugurate a discussion that is long overdue." ${ }^{43}$ No wonder the minutes of those tormented debates were never published in extenso.

In retrospect, and generally speaking, the "Marxism" voiced within CIAM was certainly more of the Stalinist type than of Trotskyist (or anarchist) origin. Trotsky's theories about art and revolution had profoundly influenced Surrealism, yet they found little echo within the congress. They smouldered in related artists' groups such as COBRA, however, not to mention the fact that Trotskysm would indeed soon help to ignite the "revolution" envisioned by the Internationale Situationniste. Already in 1947, the year of the Bridgwater congress, the Danish painter Asger Jorn, a founding member of the coBRA Group, and subsequently an active Situationniste, began to voice a solid metaphysical disgust for all that Le Corbusier (and, by implication, the CIAM) stood for: "The 'fundamental joys' in people's lives are not 'sun, air, and green trees," he proclaimed,

but rather the chance to develop, exploit and enjoy their creative powers and abilities to the benefit of themselves and those around them. This presupposes that each man is able to draw the maximum benefit from his work, food, clothing, housing, light and air; and instead of an aesthetic enjoyment of green tree tops seen from a pigeon's perspective 50 floors up in a tower block, an active relationship with nature is required where he, as a free man, can be involved in shaping his surroundings without hindrance - to fashion them according to his needs and experience, and that includes the architecture around him—-should he so desire. 
Jorn then goes on to invoke "spontaneity" as the secret of this revolution: "For this is only the beginning of a new dawn which not only heralds a new form of living and building but also a new artistic development of enormous scope and potential." ${ }^{44}$ Note that a succession of poignant essays on the interaction of architecture and the arts in Le Corbusier's work had preceded these critical remarks (indeed, Jorn knew Le Corbusier well: while studying with Léger in Paris, he had been one of those to give the architect a helping hand in making the "Pavillon des Temps Nouveaux"). ${ }^{45}$ "Instead of cultivating life itself, Corbusier cultivates common sense logic," Jorn then states. ${ }^{46}$ He continues,

... the winds of change will blow down this carefully constructed house of cards. In the new age that is dawning, mankind will turn their backs on autocratic designers who claim to design on their behalf; be that in housing, town planning, regional development etc.. People will grow and encourage others to grow, people will live and let live. ${ }^{47}$

The man who, within CIAM, probably came closest to such views was Aldo van Eyck. He was a friend of Karel Appel, Constant Niewenhuys and other Dutch members of the cOBRA Group. When van Eyck famously sprang up shouting: "To hell with common sense!" (in his response to the "Stalinist" ideologues at Bridgwater), Jorn would probably have agreed. At the same time, van Eyck's fervid exclamation also struck a decisive chord with the CIAM consensus as it had been defined and nurtured by Giedion for decades. Nor is the twin reference to "existentialism" and "humanism" in his subsequent statement a mere coincidence. Architecture follows the same logic as any other creative activity, van Eyck insisted; here, too, the question that needs to be asked is "how to make explicit the natural course of existence, by man and for man." 48

By placing Le Corbusier's "Grille ciam" and the Unité d'habitation, then still under construction, at the center of the debate, the subsequent meeting at Bergamo managed to re-focus the debate on values and procedures 
Ciam's Ghosts. Le Corbusier, Art, and World War iI
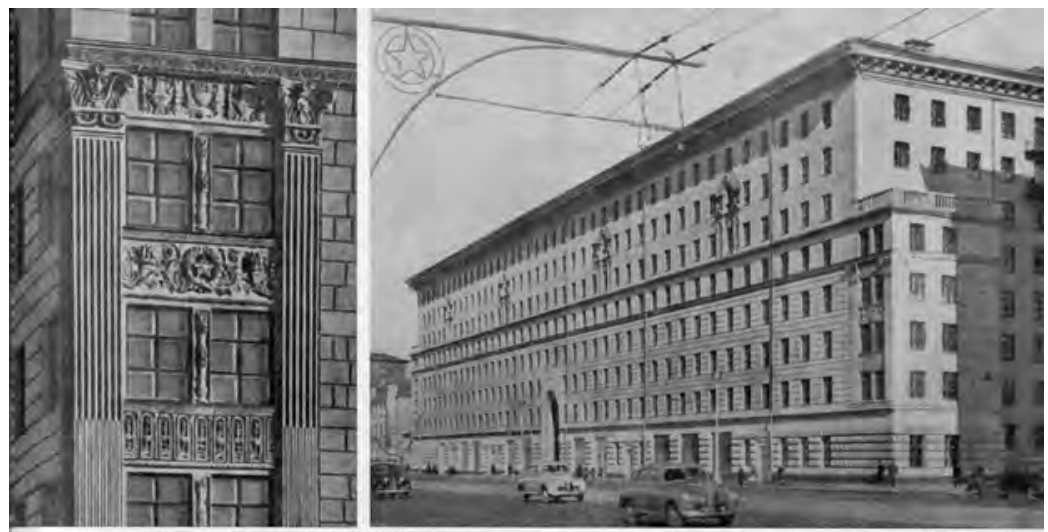

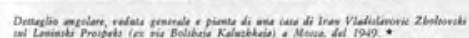

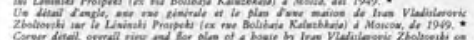

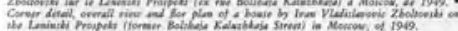
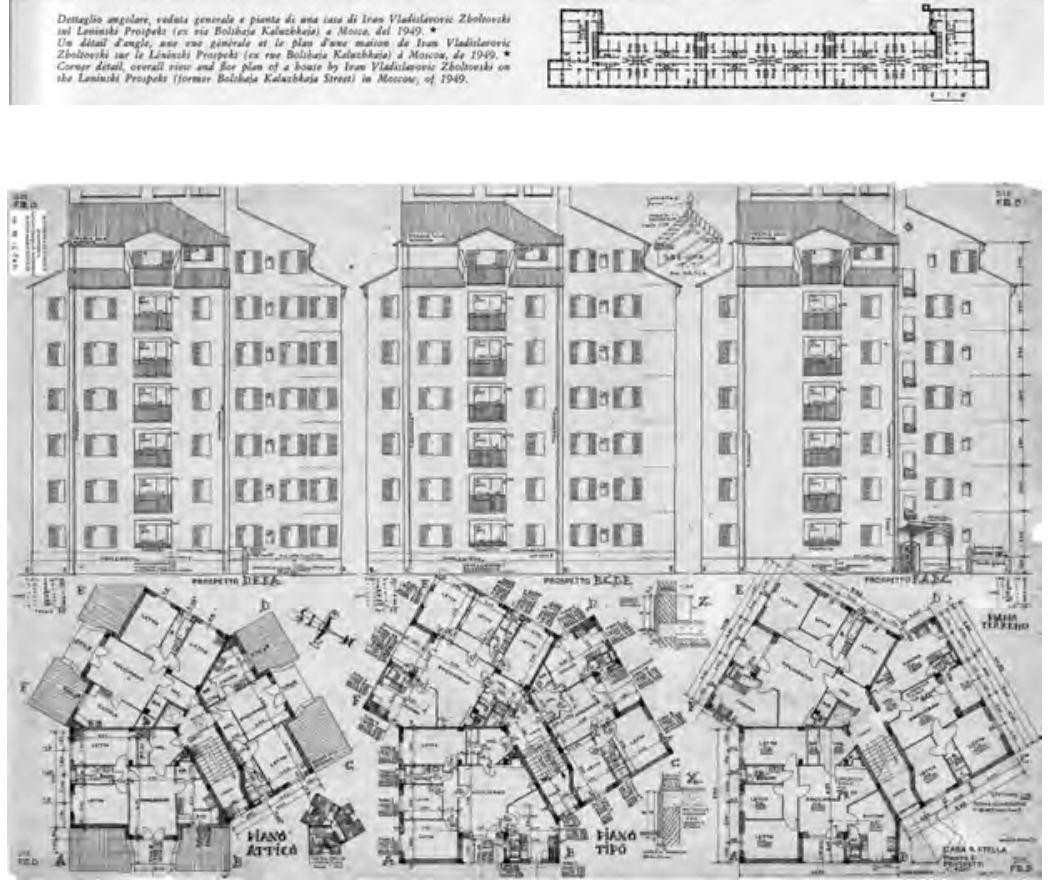

10. Ivan Zholtovski.

Housing complex on Leninski Prospekt,

Moscow, 1949.

Page from Casabella, no. 262, April 1962.

11. Mario Ridolfi.

Quartiere ina A Casa Tiburtino, Rome. Plot F, building 3. (1951).

Elevation and plan, November 28, 1951.

Courtesy Accademia Nazionale di San

Luca, Roma. Fondo Ridolfi-Frankl-

Malagricci, www.fondoridolfi.org. 
that had matured within cIAm over the two decades of its existence. The highly official construction site in Marseilles met with the vivid curiosity it deserved, not to mention acclaim for the unquestioned master of ciam. As to the prejudices still held by some against the avant-garde's aesthetic elitism, the Unité after all rather confirmed them. What is more, being the work of but one single artist-architect, this building did not offer a real answer to CiAm's earlier plea for an "Integration of the Arts" that would result from a collective effort. Consequently, enthusiasm was far from ubiquitous at Bergamo. And while Giedion later praised the completed building as the model for a visionary combination of "social" and "spatial imagination," Italian architecture set out to develop its own answers to the pressing challenges of reconstruction, developing its own vision of urbanism's symbolic and communicative potentialities. ${ }^{49}$ The Quartiere Tiburtino, in Rome, partly made possible by Marshall Plan funds, is just one example of the way those "realist" design strategies cIAm had attempted to put under quarantine subsequently became the basis for a new approach to social housing. Within a few years, Italian "Neo-realismo" thus managed to eclipse the ghost of Soviet Monumentalism (Figs. 10, 11). ${ }^{50}$

As to the ghost of "the man in the street," it was not eradicated for good. Doubts regarding the providential nature of the aesthetic avantgarde and its self-declared leadership in matters of architecture and city planning had been rumbling throughout the history of Team X, although the esprit de corps was effective at keeping them under control. ${ }^{51}$ However, a growing resistance against accepting the language of Modernism as the sole interpreter of people's needs would soon find new advocates outside the world of CIAM, and in particular among sociologists and urban theorists such as Henri Lefèbvre (in France), or Herbert Gans and Denise Scott Brown (in the USA). 
Ciam's Ghosts. Le Gorbusier, Art, and World War iI

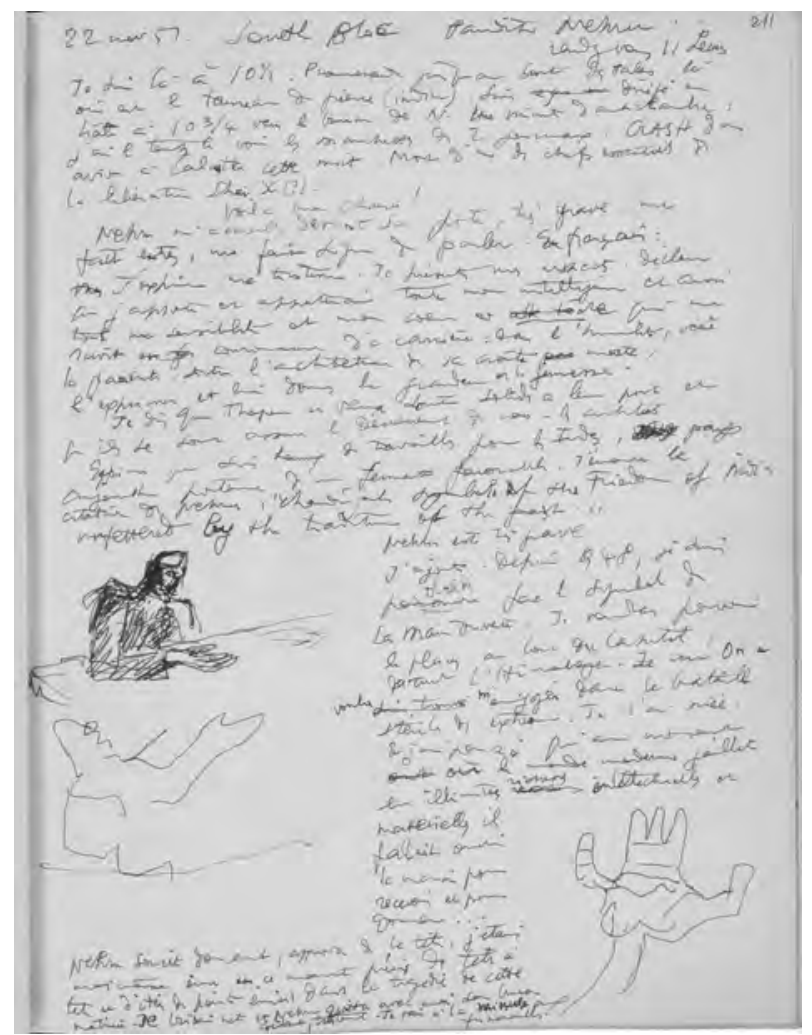

12. Le Corbusier.

Notes taken after his encounter with

Prime Minister Nehru in New Delhi,

November 22, 1951, with sketch of the Monument of the Open Hand.

Cahier Nivola, 211. 


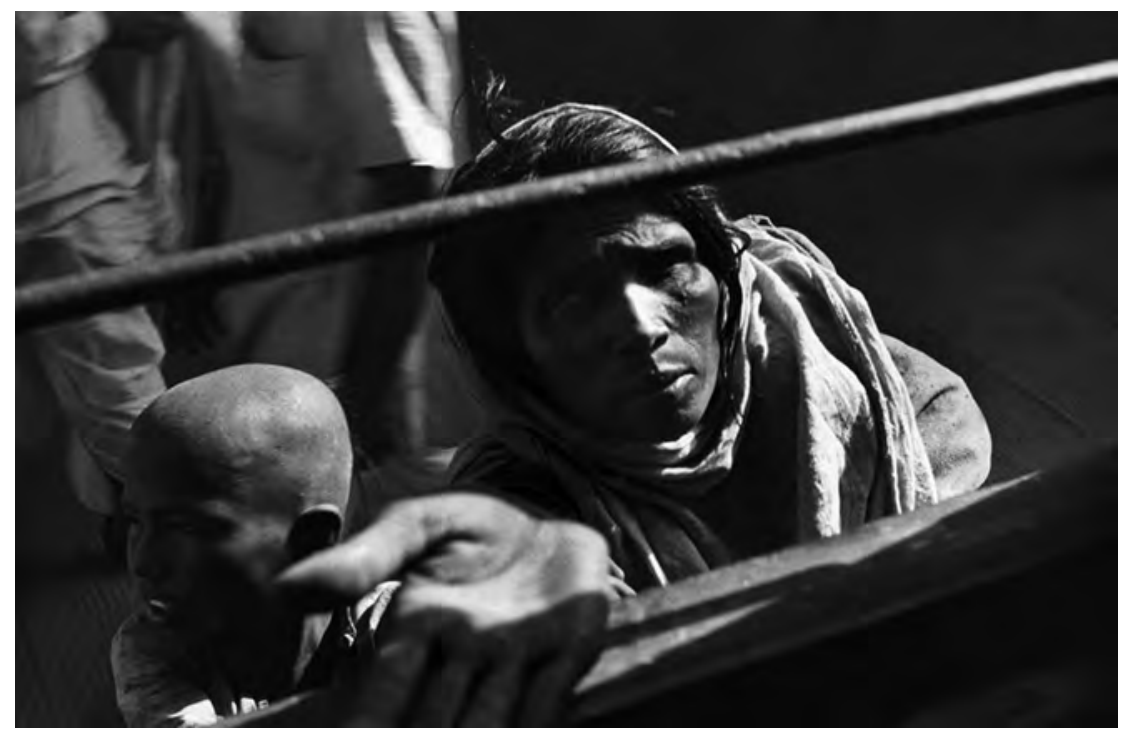

13. Werner Bischof. An Indian beggar. Photograph (1951). From $d u$. 


\section{The Open Hand and "Eternal Man"}

Chandigarh was founded in 1950. As is well known, the "Open Hand" had been imagined by Le Corbusier as a kind of logo to be planted at the edge of the city's Capitol area (Figs. 12, 17). Its outlines recall those of a trophy in the shape of a cup. At closer inspection, one could almost mistake it for a giant baseball glove. ${ }^{52}$ Although the form speaks the language of popular symbolism, the message is lofty: as a gesture, it can be seen as a pledge declaring the government's determination to distribute the riches of progress among the people, as is the role of the modern welfare state. This, at least, is how the architect may have wanted the monument to be understood by its client, even though statements such as "pleine main j'ai reçu, pleine main je donne" "“with full hands I have received, with full hands I give") suggest that the "Open Hand," as we now find it on letterheads, book covers, exhibition catalogs, even medals, is nothing less than a substitute for the architect himself: it stands for his signature. Due to the mystery of its mytho-poetic aura, this signature evokes Rudolf Steiner no less than Joseph Beuys, yet its origin is obviously Nietzschean: "I would like to give away and to distribute, until the wise among men will again rejoice in their foolishness and the poor in their richness." Furthermore: "This, in fact, is the hardest task of all: to close, out of love, the open hand and maintain, in the act of giving, one's shame." 53

Chandigarh would not exist had not India's central government agreed to cover one third of the city's estimated building costs. The decision was eminently political. ${ }^{54}$ An important purpose of the city was to serve as a memorial to the 500,000 people who had fallen in the savage war with Pakistan - a war that had cut the Punjab into two halves - and to offer work to, and hopefully a roof over the heads of, at least some of the 12 million who had lost their homes in the war. Moreover, for Prime Minister Nehru the project offered a unique occasion to efficiently stage the newborn nation's will to find its own way towards modernization, regardless of the macro-political situation and the hegemonic claims of both Washington and Moscow that 


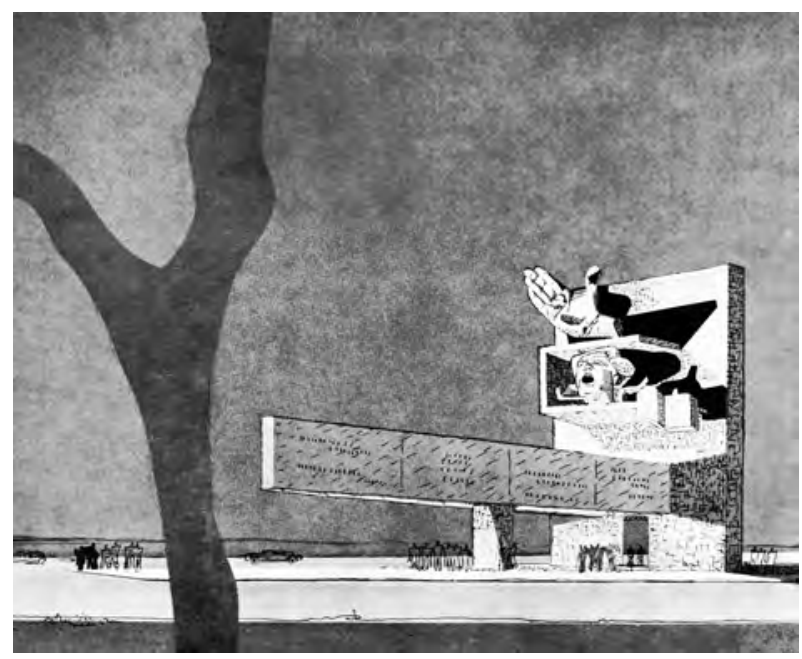

14. Le Corbusier.

Monument for Paul Vaillant-Couturier, Paris (1938).

From Euvre complète, 1938-1946.

15. François Rude.

Le Départ des volontaires (La Marseillaise), 1833-1836.

North-east pillar of the Arc de Triomphe, Paris.

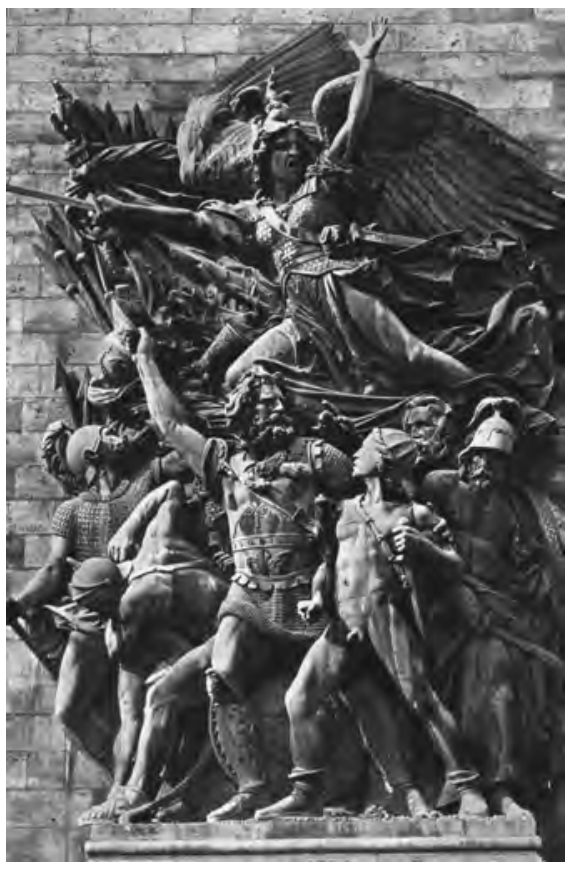


went along with it. It is important to remember how much the former enemy, Pakistan, was (and still is) enmeshed with the US, reason enough for India to invest even more energy in the demonstration of its autonomy. One can therefore understand why Nehru, who a few years later, in 1955 would join forces with other Third World leaders towards forming the Non-Aligned Movement (at the Asia-Africa conference in Bandung), responded with a smile when Le Corbusier entertained him with his maverick ideas about political neutralism. It was but one of the many attempts by the architect to lure his patron into building the "Monument of the Open Hand." "55

At one point he claims to have borrowed the idea from some sketch done in $1948 .^{56}$ Yet there is a much closer precedent: his unrealized project for a monument to Paul Vaillant-Couturier, of 1938, a huge construction to be erected at the bifurcation of a national highway outside Paris. Forming a kind of city gate, and made of mounted vertical and horizontal planes supporting and framing a face and an open hand in the act of addressing a mass rally, the project is rather pompier (Fig. 14). In its inflammatory pathos, it almost equals the work that transpires to be its model: Le Départ des volontaires, also called La Marseillaise, the sculpted relief on the south-east pillar of the Arc de Triomphe in Paris, facing the Champs Elysées (1833-1836). This is a singularly pathetic glorification of French military triumphalism, and certainly one of the most widely shown pieces of public statuary in France (Fig. 15). Both the head and the huge hand in Le Corbusier's project are inspired by (although not actually copied from) the famous work by François Rude, and then grossly enlarged and "pasted" into the abstract "pastiche."

Le Corbusier's monument to Vaillant-Couturier was to honour one of the great figures of the French Popular Front. But why this "baroque" emphasis on the hand? The monument appears to have offered an occasion to literally lift out a theme Le Corbusier had been obsessed with in his paintings for years. To the degree that painting is about human emotions, or more precisely, passion - and Le Corbusier's painting certainly was — hands, either ecstatically gesticulating or convulsively entangled, seem to be topical for this painter (as with Caravaggio or Delacroix; see also Fig. 2). On the 


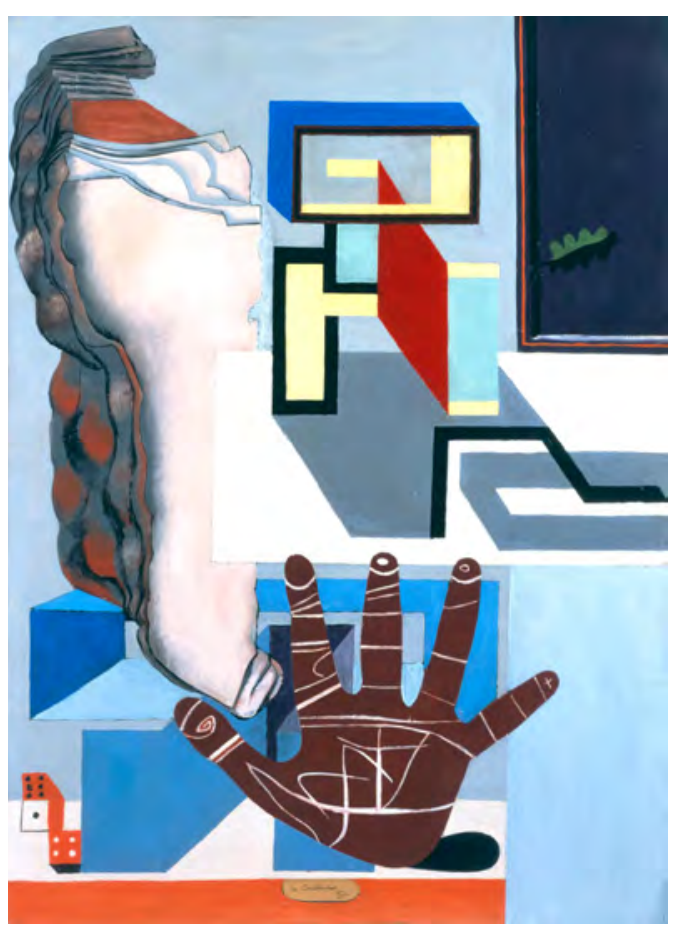

16. Le Corbusier.

Les lignes de la main.

Oil on canvas (1930).

17. Amédée Ozenfant.

Foundations of Modern Art (1931;

originally published as $A r t)$.

Cover design based on prehistoric palm prints from cavern of Les Eyzies, France.

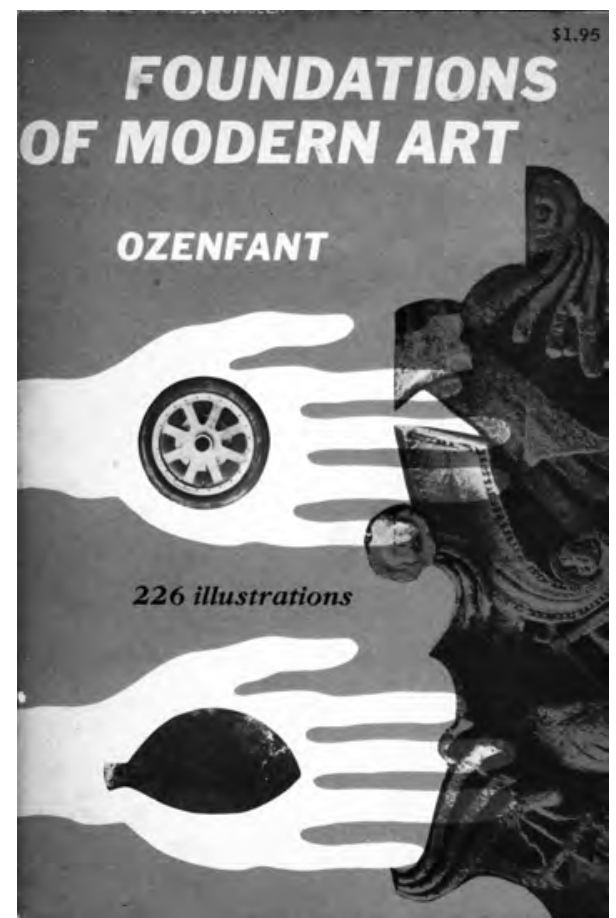


other hand, the project's reference to 19th century public statuary makes it singular within the architect's oeuvre, nor should one forget that holding out one's hand is a formula with its own history in political rhetoric. Can Le Corbusier not have been aware of the clarion call of Maurice Thorez, the secretary of the PFC (Parti Communiste Français), to the French workers in favour of a cross-party "Reconciliation of the people of France" ("réconciliation du peuple de France") in 1936? "We are holding out our hand to you," Thorez declares in this speech: "Catholic, worker, employee, craftsman, farmer, we who are secular. For you are our brothers . . . (etc.)." ${ }^{958}$ Though Thorez's conciliatory initiative did not outlast the political coalitions that constituted the Popular Front, it can be seen as the first step towards what later became known as the Christian-Marxist dialogue. ${ }^{59}$ That the philosophical credo invested in the monument turned out to outlive party politics would have been wholly in Le Corbusier's spirit. ${ }^{60}$

Clearly, for a celebration of India as the harbour of world peace, political imagery would need to be anchored in a more primeval and also a more universal idiom than the one chosen in 1938. As it happened, Le Corbusier's visual memory held a stock of images that promised to fit the occasion in an almost providential way. The hand as a primeval symbol had been on Le Corbusier's mind since the days of L'Esprit Nouveau. He knew about Abbé Breuil and the prehistoric hand prints Breuil had discovered in the caves of Pech-Merle and El Castillo in around 1910. Les lignes de la main, a painting of 1930, is a late tribute to the primeval symbolism of the palm prints inscribed on these walls - at the same time, one cannot help being reminded of Ozenfant, Le Corbusier's former brother-in-arms, who in 1928 returned from a visit to the caverns of Les Eyzies exclaiming:

Ah, those HANDS! Those silhouettes of hands, spread out and stencilled on an ochre ground! Go and see them. I promise you the most intense emotion you have ever experienced. Eternal Man awaits you (Figs. 16, 17). ${ }^{61}$ 


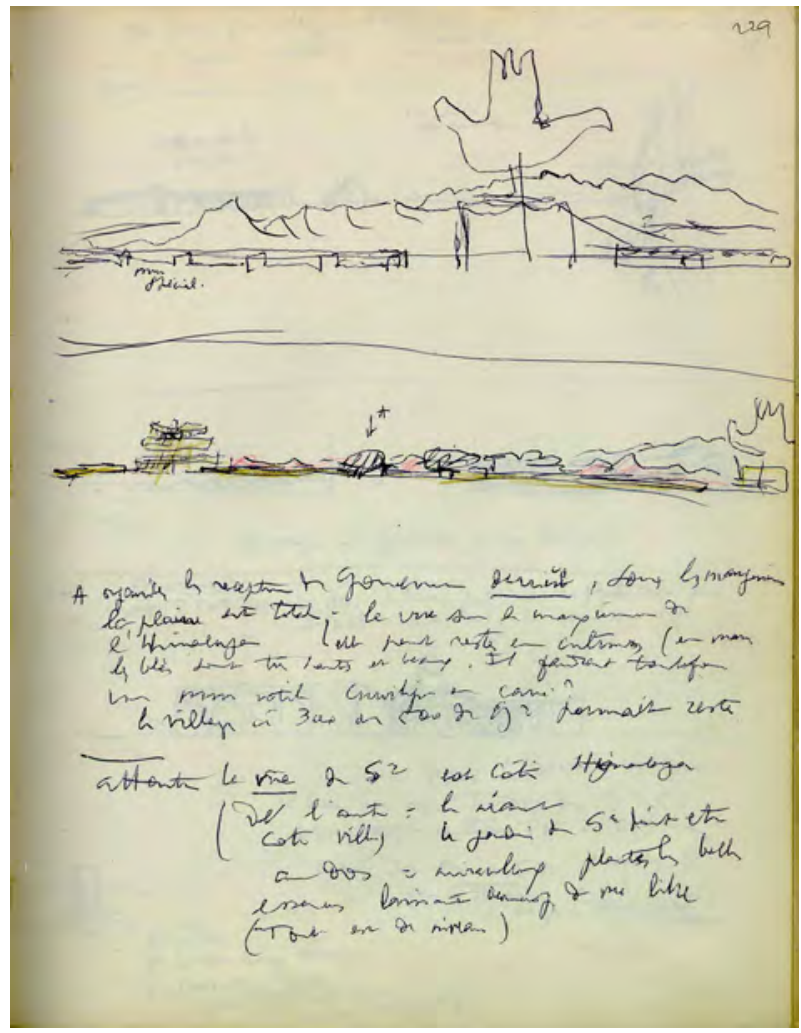

18. Le Corbusier.

Sketch of the proposed Monument of the Open Hand (1951 or after).

Cahier Nivola, 229. 
Indeed, while Le Corbusier was entertaining Nehru with his ideas about the "Open Hand," Georges Bataille and somewhat later Sigfried Giedion were initiating a new round of discussions and reflection on the meaning of these signs. ${ }^{62}$

Yet the blind passenger carried along with Le Corbusier's "Open Hand," enviously implied, silently refuted, is Picasso's peace dove. As to the Prime Minister, he mustered but limited interest in his visitor's attempts to provide evidence for his dedication to the philosophy of "neutralism." He made it clear that the execution of the proposed monument was unlikely in the near future for financial reasons. Obviously, as a savvy politician, he knew only too well how easily the public effect of political gestures and symbols could subvert the very contents those gestures and symbols intended to convey. What, for instance, if the world at large would interpret the "Open Hand" as yet another rendering of the "Empty Hand"? Indeed, this was a worrying thought given the deadly famine that plagued India at the very moment of the Prime Minister's dialogue with Le Corbusier. In a long series of haunting photographs, taken in 1951, Werner Bischof documented the reality of "the smashed, the crooked, the beggar's hand, India's second face" (Adolf Muschg; Fig. 13). ${ }^{63}$ No wonder the realization of a monument whose symbolism would make it so vulnerable to misunderstanding did not make it to the top of the political agenda.

\section{Ruin Exorgism, and the Nuglear Sublime ${ }^{64}$}

One way of finding out what makes people look at ruins may be to explore the reasons why, in certain circumstances, they categorically refuse to do so. ${ }^{65}$ For many years, the mental block regarding the experience of ruin appears to have been more widespread even among architects than among ordinary people. If Anthony Vidler is correct, architectural discourse in England was characterized for decades by "a culture of suppression and conscious self-deceit with respect to the psychological damages of war." 

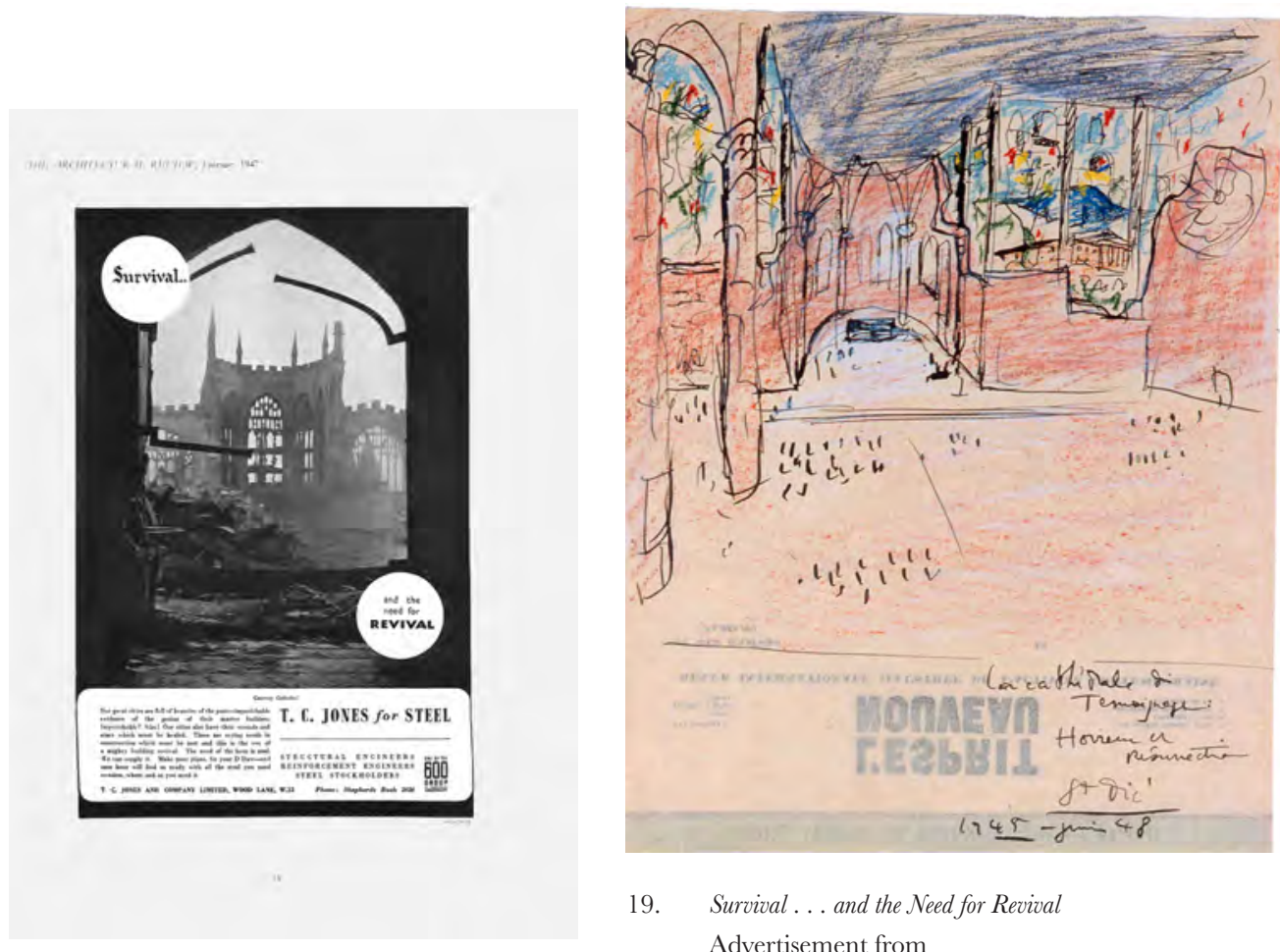

19. Survival ... and the Need for Revival Advertisement from

The Architectural Review (1947)

showing the bombed nave of

Coventry cathedral.

20. Le Corbusier.

The Cathedral of Testimony. Horror and resurrection. Ink and colour pencil drawing on the reverse of a sheet of L'Esprit Nouveau stationary.

Dated "June 48." 
Yet the clean-up was certainly not total in England. Before the bombings had come to an end, Kenneth Clark rationalized the effects of war by simply stating that "war damage in itself is picturesque." ${ }^{\text {" A }}$ A lost drawing by Louis Kahn basically makes the same point when it suggests that Europeans should use their bombed churches as war memorials (also in 1944). ${ }^{68}$ Many among London's bombed churches eventually survived as war memorials in the form of picturesque urban amenities, thanks to this strategy. Coventry cathedral has thus become a symbol of Britain's rebirth after the war (Fig. 19), as has, mutatis mutandis, the badly damaged Kaiser Wilhelm-Gedächtniskirche in Berlin, although, not by coincidence, the Gedächtniskirche is also the latecomer in this series (completed 1958-62).

Le Corbusier's plan for the rebuilding of Saint-Dié is a key example of "ruin exorcism." Except for some pre-19th century artefacts considered to be worthy of preservation, the plan virtually ignores the city's historic street pattern. The "New" is defined by its radical opposition to the "Old." Granted that in comparison to the 1930s visions of the "Ville Radieuse," the nervous gesture of the late Saint-Dié renderings now evokes a rather broken version of the "New": in an encrypted way, these drawings seem to speak of violence, of dark materiality, as if involuntarily reflecting the sombre experience the country had just gone through. ${ }^{69}$ In the background of one of those drawings, one notices the 17th century towers of the cathedral and the ruined gothic nave covered by some sort of emergency roof (Figs. 21, 22). By 1948, while it had become clear that the famous master plan for Saint-Dié would be shelved, the idea of the ruin as war memorial had resurfaced on the agenda (see Fig. 20). Charged with ideas of martyrdom and resurrection, the proposal for the "cathédrale du témoignage" in Saint-Dié resonates with the architect's upbringing. At the same time, memories of World War I appear to have had a share in this reawakened interest in ruin symbolism: in 1915, in the early months of the war, German artillery had attacked Reims cathedral, a trauma that caused an uproar far beyond France and that had ultimately been decisive for the architect to choose France (instead of Germany) as his field of action. ${ }^{70}$ 
21. Saint-Dié, France.

View of ruined city centre after the cleaning up of the ruins, ca. 1947.

22. Le Corbusier.

Sketch illustrating Le Corbusier's plan for the reconstruction of Saint-Dié, showing the city administration tower (right) and the cathedral (background; 1945).
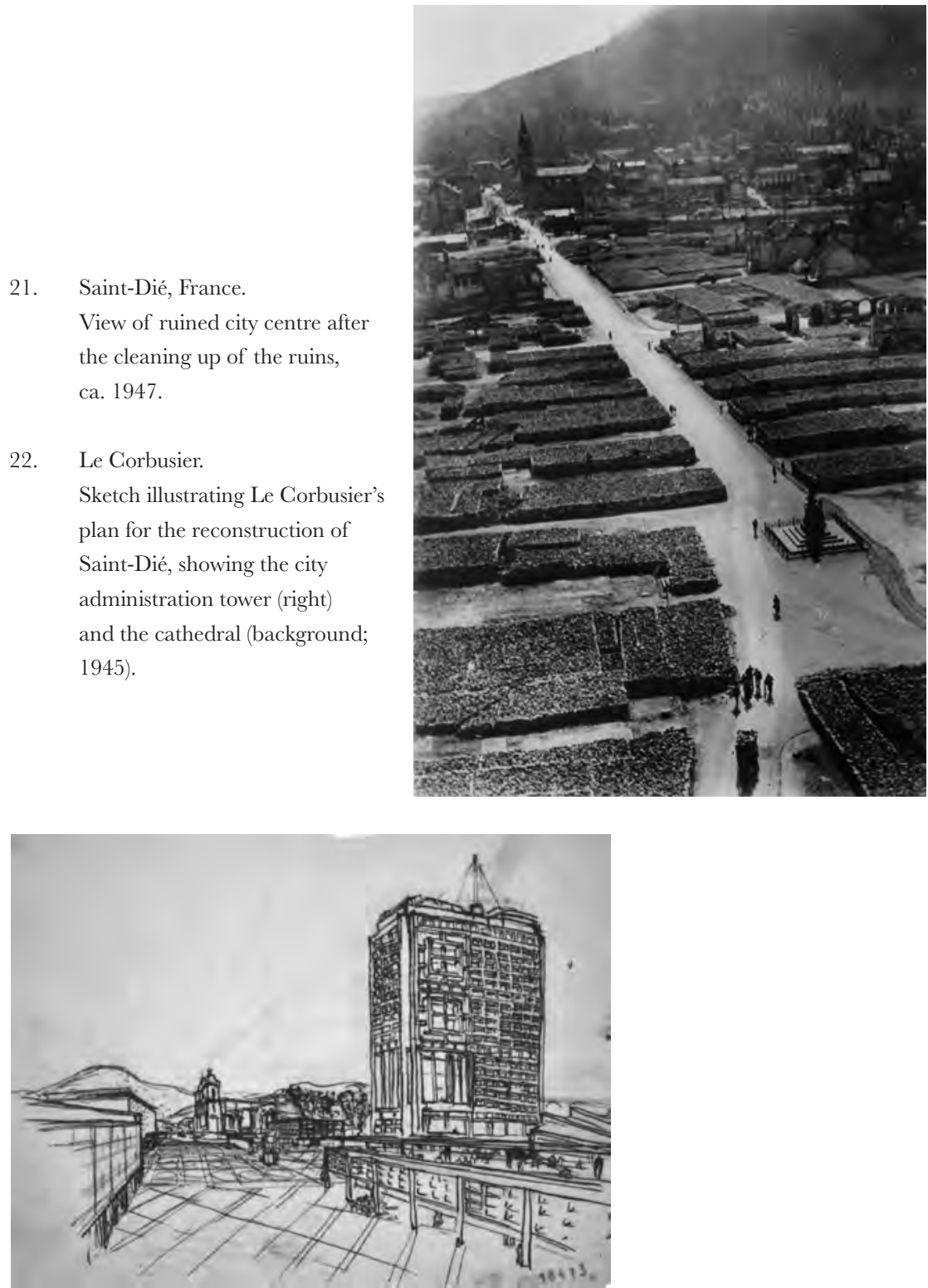
Should the project's rough materiality and tragic aura be seen as a first step towards Brutalism (Fig. 20)? ${ }^{71}$ At the very least, that quality appears to be a belated acknowledgment of the brutality of ruination that had triggered the abstract program of the master plan to begin with. The architecture thus incorporates both the horror of war and the triumph of resurrection ("horreur et résurrection," as is noted on the drawing). The idea never reached the project stage. The cathedral's nave as well as the adjacent cloisters now survive in the form of a reconstruction à l'identique. ${ }^{72}$

Speaking of exorcisms, one wonders if Reyner Banham's exploration and canonization of "New Brutalism" should not, after all, primarily be understood as an effort to exorcize the preceding fashion launched by the Architectural Review: "New Empiricism."73 Banham is quite explicit about this aspect of his campaign when he pours sarcasm over that movement's "cottage-sized aspirations" and its "sentimental regard for nineteenth century vernacular usages." For him, its tendency to "elaborate woodwork detailing," its "pitched roofs ... pretty paintwork and freely picturesque grouping on the ground," etc., deserve ridicule. He knows that, granted an input of British socialist ethos, the origins of the style are Swedish (he reports James Stirling stating "Let's face it, William Morris was a Swede!"74), but he cannot resist the temptation to add political spice to the argument by associating those petty aspirations with "conscious attempts by architects committed to the Communist line, to create an English equivalent of the Socialist-Realist architecture proposed in Russia by Zhdanov's architectural supporters." With a "grotesque mixture of Stalinist conspiratorial techniques (and) the traditional methods of British snobbery," these architects attempt to "enforce an Anglo-Zhdanov line," he writes, thus defining the "picturesque" as yet another layer of exorcism, this time at the expense of Soviet neo-classicism (see Fig. 10). ${ }^{75}$

The animosity is surprising. Though England had its own, steadfast tradition of state classicism, and one that survived well into the postwar years, no one would associate it with Stalinist politics. Certainly, the Communist cause in Britain was considerably weakened by 1951, when the Conservative 
Party returned to power, and by 1954, when Krushchov's verdict gave "Socialist Realism" its coup de grâce, Communist state art no longer served as a model, even in the most orthodox Communist circles in the West (see Fig. 10). ${ }^{76}$

Yet Banham has a point when he suggests that the short conjuncture and rapid demise of "Socialist Realism" in Britain, the homeland of Socialism, created a vacuum that invited an extravagant flourishing of less politically motivated discourses on "reality" and, by implication, "real-ism." What mattered, in the end, was hardly the alleged politics of the Toronscape movement, or the politics of such books as Castles on the Ground by J. M. Richards (1946; see Fig. 6); ${ }^{77}$ rather, what was at stake was the notion of "reality": according to this critic, the "reality" of a bucolic landscape or a picturesque village, or of the "genius loci," which "seemed of absolutely trivial value to a younger generation." In the eyes of that generation, the reality that needs to be dealt with is the reality of "social chaos, a world in ruins, the prospect of nuclear annihilation." "78 With their two "exhibition pieces" of 1956, Alison and Peter Smithson had demonstrated what Banham had on his mind when he defined architecture as a way of digging into the substance of war memory and war anxiety. The first piece, "Patio and Pavilion," shown at the "This Is Tomorrow" exhibition at Whitechapel Gallery in 1956, was a simple wooden structure, resembling an East End garden shed furnished with "bits of homely junk," the whole thing looking as if it had been "excavated after the nuclear holocaust."79 The second piece, the "House of the Future," shown a few months later at the "Ideal Home" exhibition again in London, was an integrated model home, made of streamlined elements, assembled like a car, and thus, albeit not made of metal but of plastic, could be classified as "Pop." It was totally self-contained and oriented towards the interior: perfectly safe, the ultimate bomb shelter. ${ }^{80}$

What, then, would be the appropriate model for architecture to adopt in a world of social chaos, ruins, and the prospect of nuclear annihilation? For Banham's generation, for the generation of the Brutalists, the answer was Le Corbusier, Mies, or - perhaps surprisingly — PhilipJohnson (the Glass House 
Ciam's Ghosts. Le Corbusier, Art, and World War ii
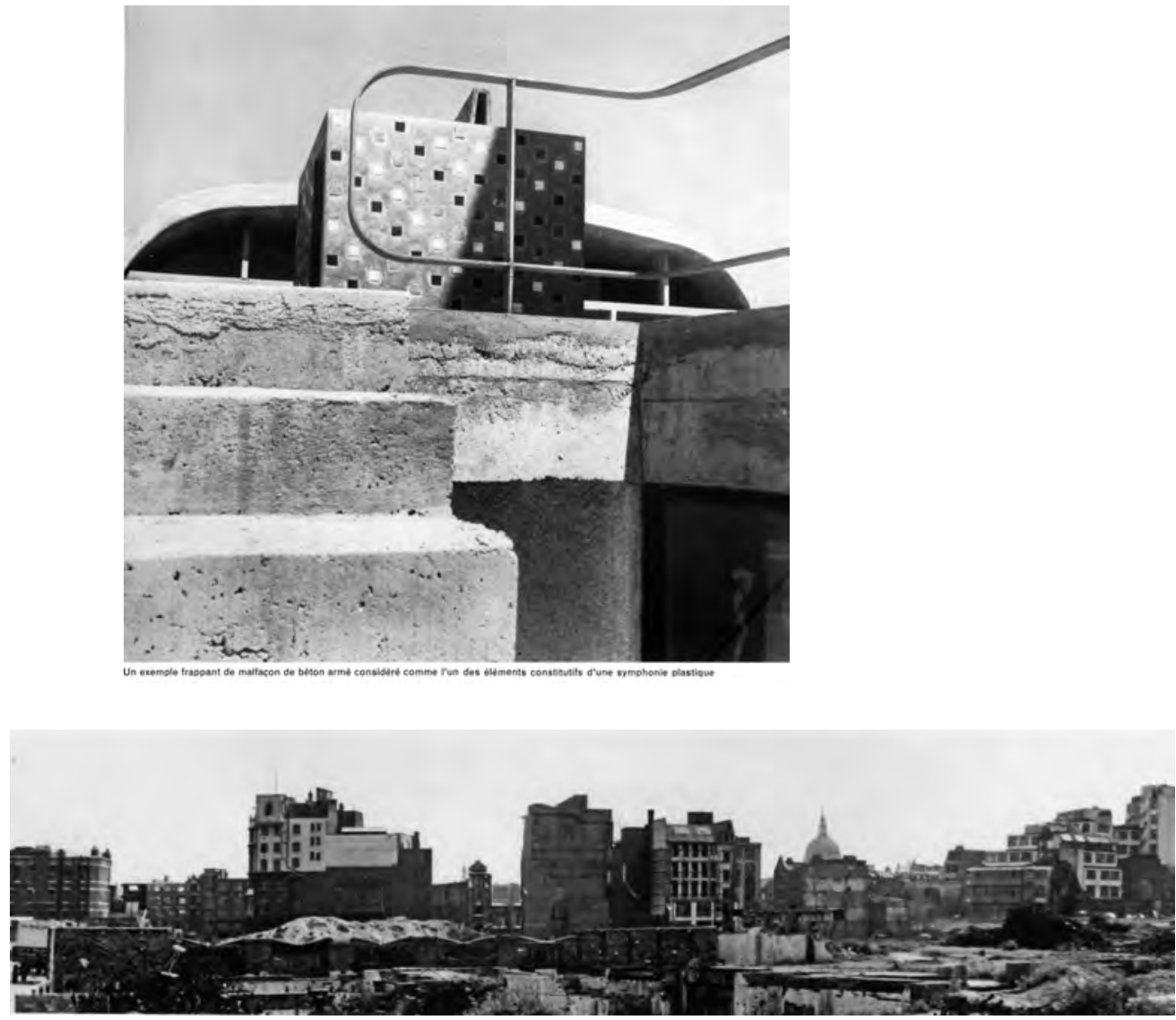

23. Le Corbusier.

A striking example of badly executed reinforced concrete considered as one of the constituent elements of a plastic symphony.

Photo from the roof terrace of the Unité d'habitation,

Marseilles, with caption from Euvre complète, 1946-1952.

24. Peter Smithson.

View of the Golden Lane neighbourhood after bombing, ca. 1945 .

The photograph was later integrated by Alison and Peter Smithon into their Golden Lane housing project (1952).

Courtesy Smithson Family Collection 
in Greenwich, CT). This may have been why the "Angry Young Men" of British architecture invaded the 1951 ciam congress in Hoddesdon "in order to sit at the feet of the 'grands maitres' whose views they could respect," while the "English seniors," whom they despised more and more, continued indulging in discussions on the relevance or not of the "Picturesque tradition" for architecture. ${ }^{82}$

\section{Marseilles, Ruins, and the Myth of Eternal Return}

No Modernist building has been associated as persistently with ruin as the Unité d'Habitation, in Marseilles (1947-52). According to Banham, the traces of wooden coffering on the surfaces of the stairs, walls, chimneys, exhaust shafts, and elevator towers on the roof terrace make these look "like ruins." "The concrete work of Marseilles started as a magnificent ruin even before the building was completed," Banham writes. ${ }^{83}$

The malfaçons that resulted from the construction workers' lack of experience with on-site cast concrete, swiftly reclaimed by Le Corbusier as "noble rudeness" (since repairs would have been virtually impossible, Fig. 23), are only part of the problem, although it is these technical defects that "produce an architectural surface of a rugged grandeur that seems to echo that of the well-weathered Doric temples in Magna Graecia." ${ }^{\prime 4}$ In fact, according to Vincent Scully, it is by virtue of their plastic power that the "sculptural drama" of Le Corbusier's late works (Unité, Ronchamp, and the High Court Chandigarh) is linked to the Greek experience: for Scully they are all "primitive Greek temples, sculptural bodies in whose gestures we feel a modern violence." As to the "muscular giant" of the Unité, he explicitly turned to maritime and military metaphors: "The Unité is a giant, a temple, an aircraft carrier," he writes. "Its pilotis are the legs of a colossus, a bomber's tires; the shapes of its roof are maritime, a medieval city, a dirigible's hangar. The roof is a mountaintop itself" (Fig. 25). ${ }^{85}$

These implications of primitive violence do not make the Unité a 
Giam's Ghosts. Le Gorbusier, Art, and World War il

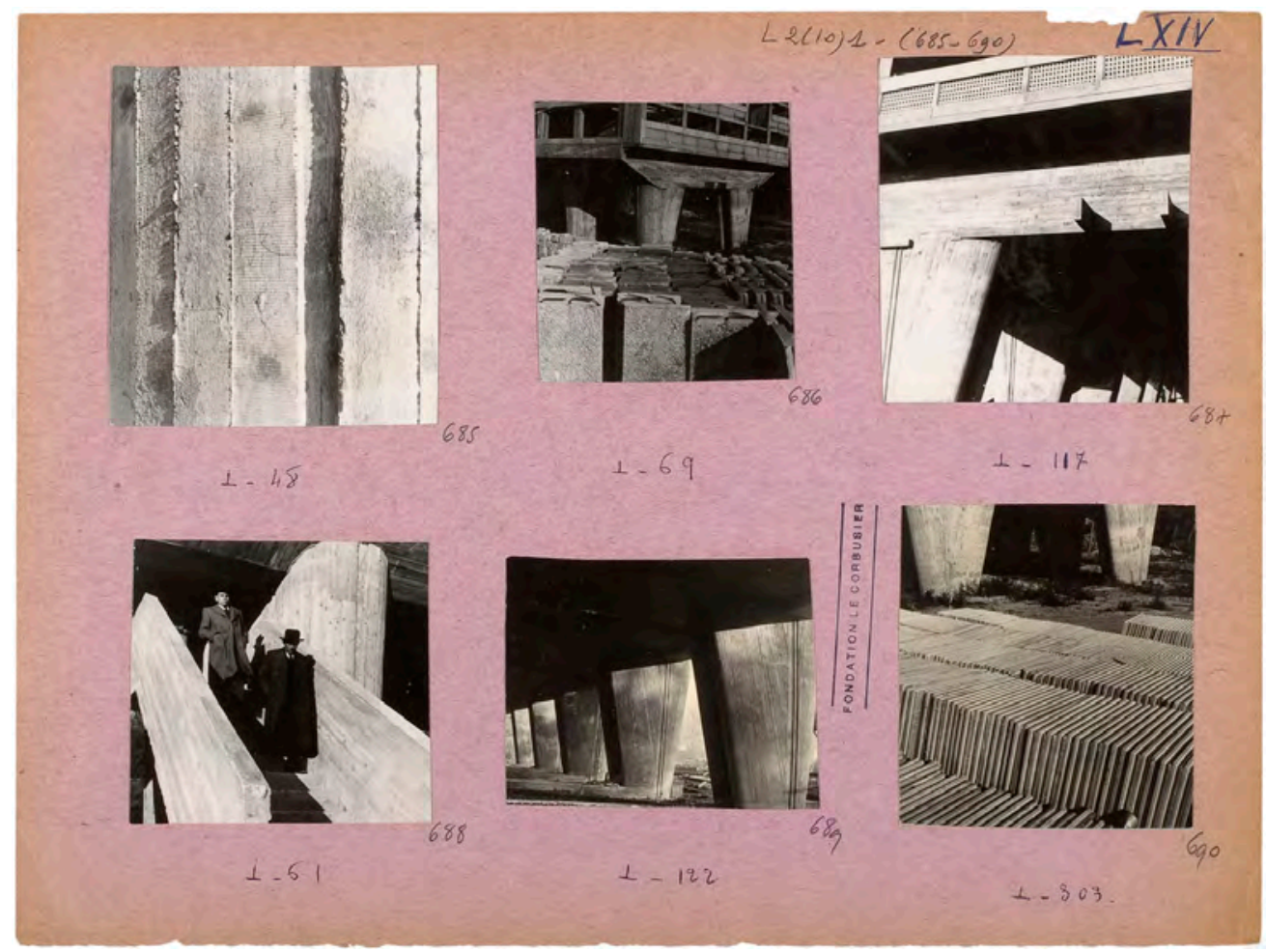

25. Lucien Hervé.

The construction site of the Unite d'Habitation

in Marseilles.

Contact sheet; undated, ca. 1950.

Courtesy The Getty Research Institute,

Los Angeles 
war memorial, however, even though "Marseilles was built on top of a battlefield," as the architect once wrote. In 1952, when the Unité was about to be completed, the Smithsons used photographs of London's bombed Golden Lane neighbourhood to personalize their project site. The ruins were to become part of the reconstructed neighbourhood, a testament to the events London and its inhabitants had gone through during the war (Fig. 24). ${ }^{86}$ Although their project owes a lot to the Unité, the Smithsons knew very well that Le Corbusier had not envisioned anything of the sort. ${ }^{87}$ However, without the battlefield of World War II, there would have been no Unité d'Habitation to begin with. Nor did Marseilles lack its share of bombing, ruin, and cleaning up. Remember that French cities paid a heavy price in the course of France's liberation by Allied Forces and reconquest of the territory that had been under German control. Though less dramatically hit than Orléans, Caen, Royan, or Saint-Malo, Marseilles suffered 1,250 casualties during the Allied bombing in June 1944 alone. ${ }^{88}$ In 1947, in the American edition of When the Cathedrals Were White (a book dealing with New York, first published in 1937), Le Corbusier writes: "The American Army arrived in Europe, found its lands, its peoples, its cities, and its fields ravaged by four years of war, emptied and robbed, in ruins, covered with dirt and eaten with rust; found broken windows and nerves on edge, exhausted bodies, and tenacious morale." 89

That the Unité, "perhaps the most influential and controversial architectural image to emerge during the reconstruction period," 90 was also, eminently so, an "art project," is highlighted by the Picasso episode referred to at the beginning of this essay. As art, architecture cannot illustrate history and biography, except in the language of allegory and metaphor. Architecture, one would assume, is no medium for autobiographical reflection: the shape of a ventilation shaft, an elevator engine casing, a gymnasium, or a child-care centre thus are primarily determined by their functions. Within the Beaux-Arts tradition, it was possible to nobilitate such installations by way of incorporating columns, friezes, pediments and capitals (see Fig. 10). However, at the Unité, the ventilation towers emerge 
Ciam's Ghosts. Le Gorbusier, Art, and World War iI

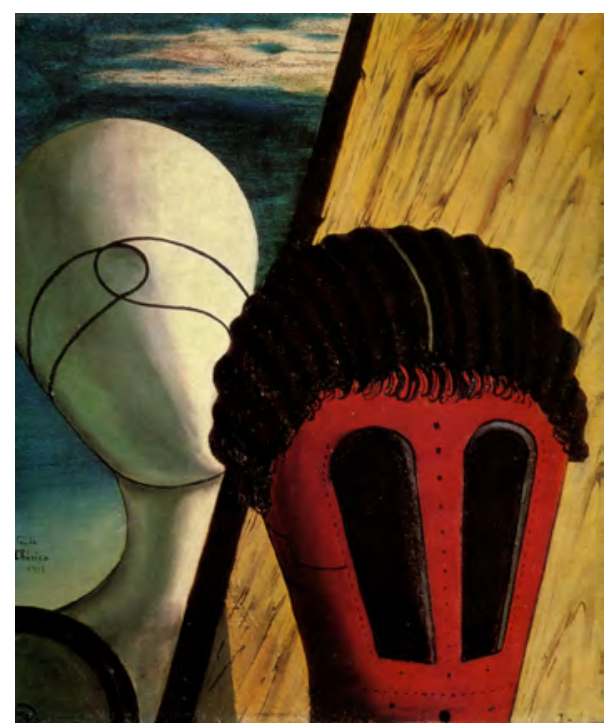

26. Giorgio de Chirico.

Two Sisters. Fewish Angel.

Oil on canvas. 


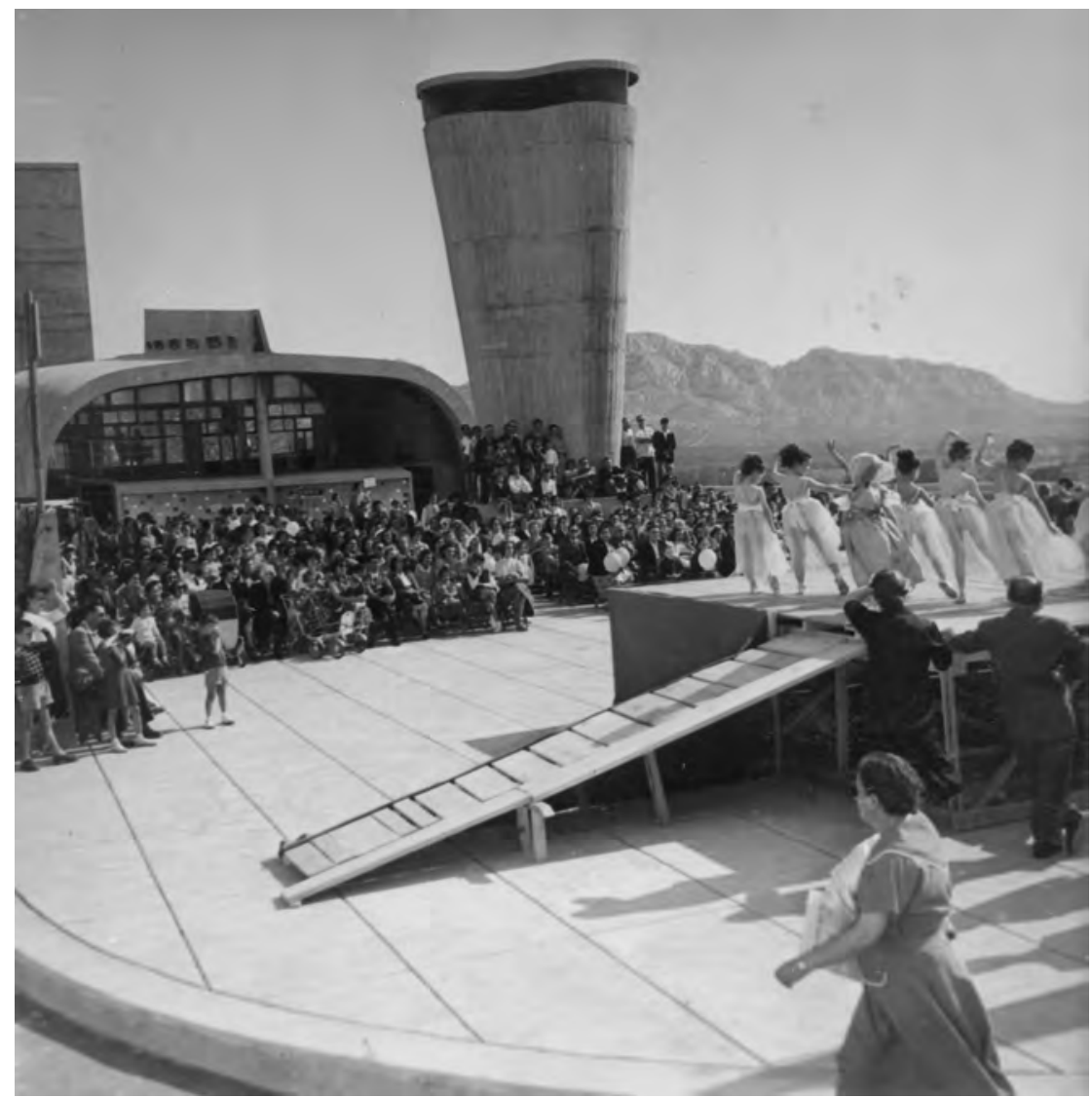

27. Unité d'Habitation in Marseilles. Roof terrace during inauguration ceremony on October 14th, 1952. Unknown photographer. 
from box-shaped podiums like sculptures; the conical ventilator shafts look like tree trunks turned upside down, ending with a small slit from where one might ultimately get the panorama that the high parapet of the roof terrace forbids. It is Morandi and de Chirico turned into a grotesque Walpurgis night (Figs. 26, 27).

Many have written about the process through which concrete architecture in the twentieth century began to cannibalize the traditional arts, in particular sculpture (Sigfried Giedion, James Hall, Alan Colquhoun, Rosalind Krauss, and Detlef Mertins) ${ }^{91}$ In the second edition of her seminal Contemporary Sculpture (1960; first edition, 1937), Carola Giedion-Welcker included a series of images of both sculptures by Le Corbusier for the Unité and its roof terrace. ${ }^{92}$ It is intriguing that while the building was under construction, in 1950, Giedion-Welcker wrote a penetrating essay on De Chirico, who had already entered the pantheon of great artists (see Fig. 26). Albeit indirectly, her comments reveal some of the more obscure reminiscences (or implied prophesies) invested in the building. "The entire world appears to survive as an abandoned theatre whose stage set is made of historic and personal reminiscences," she writes. "We see bizarre concretions of human form emerging, born from a critical stance towards the present. Figurations evoking both Greek mythology and the mechanical present in Chirico's 'manichinos' are looming over technical measuring instruments and architect's stencils like grotesque idols on fragile wooden podiums." ${ }^{\text {"93 }}$

All this throws considerable light (or shadow?) on the Unité. Concerning the gymnasium with its structurally unnecessary keel (Fig. 27), can it be read as anything other than an archaizing reference to the high-tech romanticism of the ocean liner, which is in many ways the conceptual key to the Unité? At the same time, it resonates with the fishermen's barges at Arcachon, while also being an allusion to the ship that carried Ulysses, Le Corbusier's alter ego, across the Aegean Sea, cut in half and capsized. "Born in furor," project seems similarly imbued with archaic myths, restored through the force of desire and destiny: a storm is in the air, as is the smell of blood 
and vengeance, not unlike many of Böcklin's paintings. Böcklin was a topical reference for the pittura metafisica and for Surrealism, as well as an occasionally cited name in Le Corbusier's early travel reports, but by 1950 he had obviously been forgotten. The same applies to most of the formal tropes behind the biomorphic geometries of the roof terrace. Although they powerfully reverberate with ancient memories, there is obviously no simple key for deciphering them. Barge, column, stage, the organic form of a tree trunk that embodies a memory of human form: as in Le Corbusier's painting, it is the layering of the fragments, their "automatic" interaction in time and space, "devoid of any visible link," 95 that creates the crude and irritating mystery of the situation.

\section{Notes}

1 The key text on the Unité d'habitation is by Atelier de bâtisseurs, Le Corbusier, L'Unité d'habitation de Marseille (special issue of Le Point, Nov. 1950), but the most complete critical examination of the building in its socio-political context, including also its ambiguous impact on social housing in France, is by Gérard Monnier, Le Corbusier. Les Unités d'habitation en France (Paris: Belin/Herscher, 2002). See also François Chaslin, Un Corbusier (Paris: Fiction \& Cie., 2015), 283-381 and passim for a fascinating close-up view of the project's genesis.

A preliminary version of the present essay appeared as "Brutalism's Ghosts: Le Corbusier, Art, and War," in Ruth Baumeister, ed., What Moves Us? Le Corbusier and Asger Forn in Art and Architecture (Silkeborg; Zurich: Museum Jorn; Verlag Scheidegger \& Spiess, 2015), 17-25. For background to Le Corbusier's concept of the "synthesis of the arts" see my Le Corbusier. Elements of a Synthesis, rev. ed. (Rotterdam: 010 Publishers, 2009), 264-317 as well as, more recently, Joan Ockman, "A Plastic Epic: The Synthesis of the Arts Discourse in France in the Mid-Twentieth Century," in Eeva Liisa Pelkonen and Esa Laaksonen, eds., Architecture + Art (Helsinki: Alvar Aalto Academy, 2007), 30-61.

2 See Gertie R. Utley, Picasso. The Communist Years (New Haven and London: Yale University Press, 2000), esp. 39-51; on Le Corbusier's politics, see below. 
Ciam's Ghosts. Le Corbusier, Art, and World War ii

3 Le Corbusier, Euvre complète 1946-1952 (Zurich: Les Éditions d'Architecture, 1953), 9.

4 La Menace ("The Menace," 1938, oil on canvas, $162 \times 130 \mathrm{~cm}$, private collection, Switzerland). A photomural made from the photograph was included in the 1952 Le Corbusier retrospective at the Musée d'Art Moderne in Paris. For an installation shot see Le Corbusier ou la Synthèse des Arts (Geneva: Musée d'Art et d'Histoire, Skira, 2006), 50. The picture was but rarely reproduced in subsequent years. On La Menace and its stylistic and iconographic antecedents, see Naima Jornod and Jean-Pierre Jornod, Le Corbusier (Charles Edouard Jeanneret): Catalogue raisonné de l'œuvre peint (Milan: Skira, 2005), 628-630. For a more general discussion of Le Corbusier and World War II see my "Ruin Count. On Le Corbusier and European Reconstruction," Perspecta, no. 48 (2015): 144-161.

5 See Jornod and Jornod, Le Corbusier, 596ff. Although it is with respect to another version of the painting that Le Corbusier gives these details, the analogies are sufficiently clear for the description to be transferred to La Menace.

6 From World War I onwards, Le Corbusier's painting unfolded in an almost uninterrupted dialogue with Picasso, although the subject was hardly discussed. After 1937, Guernica became a major reference. We can take it for granted that Le Corbusier not only knew the mural as such but also Picasso's preparatory studies since many of them were published in 1937 in Cahiers d'Art 12, no. 4-5.

7 "Je viens de peindre comme un forensé depuis tôt ce matin. Les inquiétudes du temps agissent et me privent de la belle tranquillité d'après-guerre" (meaning, of course, the years after wwI). Then: "Risques effroyables de guerre sans nom. Derrière tout ça: rien! Des mots, des fantômes," in a letter to his mother dated March 6, 1938; quoted in Jornod and Jornod, Le Corbusier, 628.

8 In particular La chute de Barcelone (1939, oil on canvas 70 x 103cm, private collection); see Jornod and Jornod, Le Corbusier, 664-665 as well as, for a detailed analysis of these works, Juan José Lahuerta, Le Corbusier e la Spagna: Con la riproduzione dei carnets Barcelone e C10 di Le Corbusier (Paris: Electa/Mondadori, 2006), esp. 63-65.

9 See in particular Chaslin, Un Corbusier. On fascism's "fellow travellers," who far outnumbered those actually enrolled in any fascist groups (Le Corbusier never was), see Zeev Sternhell, Neither Right Nor Left. Fascist Ideology in France (Princeton, NJ: Princeton University Press, 1996), 272, passim.

10 Von Moos, Le Corbusier, 200, 212, passim. 
Stanislaus von Moos

11 On the myth of eternal return in archaic culture see Mircea Eliade, Kosmos und Geschichte. Der Mythos der ewigen Wiederkehr, trans. Günter Spaltmann (Frankfurt a.M.: Insel, 1984), esp. 44-51, 153-159, passim.

12 Quoted after Emmanuel Rubio, Vers une architecture cathartique (1945-2001) (Paris: Éditions donner lieu, 2011), 43. Rubio mentions Le Corbusier: Textes et dessins pour Ronchamp (Ronchamp: Association (Euvres de N.D. du Haut de Ronchamp, 1997) as source. Rubio has a point when he argues that, "By ways of incorporating war destruction (the chapel) helps ruin become one of the foundations of new life," in Vers une architecture cathartique, 37. In his more optimistic reading of Ronchamp, Josep Quetglas sees the chapel as a demonstration that "ruin can be avoided"; see "Ronchamp: A Landscape of Visual Acoustics," in Jean-Louis Cohen, ed., Le Corbusier. An Atlas of Modern Landscapes (New York: The Museum of Modern Art, 2013), 212216, here 215.

13 See my "Ruin Count. Le Corbusier and European Reconstruction."

14 The "Graffite à Cap Martin" is reproduced in Le Corbusier, Euvre complète 1938-1946, 159. See my, "Le Corbusier as Painter," Oppositions, no. 19-20 (1980): 88-107. ("Author's postscript, December 1980"); for an alternative interpretation see Beatriz Colomina, "Battle Lines: E1027," in Francesca Hughes, ed., The Architect Reconstructing Her Practice (Cambridge, Mass.: MIT Press, 1996), 2-25.

15 At least according to Samir Rafi, "Le Corbusier et 'Les Femmes d'Alger," Revue d'Histoire et de Civilisation du Maghreb (1968): 50-66 (my own previously mentioned essay, "Le Corbusier as Painter," is heavily indebted to Rafi).

16 Tony Judt, PostWar. A History of Europe since 1945 (New York: Penguin, 2005), 221-225; Frances Stonor Saunders, The Cultural Cold War: The CIA and the World of Arts and Letters (New York: New Press, 1999), 45ff., 68, passim; Utley, Picasso, 106-116.

17 Utley, Picasso, 110.

18 "On veut nous renfermer dans un dilemme: usA-URss. Tel est le fruit d'une absence d'information qui ne se peut acquérir que par l'examen sur place des diversités et des similitudes qui conditionnent le présent phénomène machiniste en pleine évolution . . (etc.)." Letter to Prime Minister Nehru, printed in Jean Petit, Le Corbusier lui-même (Geneva: Éditions Rousseau, 1970), 116-117. On the encounter with Nehru see also Nicholas Fox Weber, Le Corbusier. A Biography (New York: Alfred A. Knopf, 2008), 561-563 (although the chronology as reported in the footnotes is far from reliable). 


\section{Ciam's Ghosts. Le Corbusier, Art, and World War ii}

19 The note is on the respective document owned by the Fondation Le Corbusier, Paris. On the "Congress of Intellectuals for Peace" held in Wroclaw, 1948, the founding moment of the international Peace Movement, see Utley, Picasso, 106, passim.

20 ". . . was für mich als ciam Council Mitglied eine bittere Pille war und mir viel zu denken gegeben hat." Letter to Sigfried Giedion, 17 November 1948 (Giedion-Archive at gta Institute, ETH-Z). For a more contextual discussion of post-World War II CIAM, see my "'L'Europe après le pluie' ou le brutalisme face à l'Histoire," in Jacques Sbriglio, ed., Le Corbusier et la question du brutalisme (Marseilles: Parenthèses, 2013), 66-87.

21 'Il s'amusait comme un gosse en regardant Paris du haut. Comme nous voyagions en avion spécial polonais, j’ai demandé au pilote de déscendre plus bas et de faire quelques tours audessus de Paris et puis au-dessus de toutes les villes qui se trouvaient sur notre trajet." Helena Syrkus, "Tel que je l'ai gardé dans la mémoire" (French translation of a text published in KultuRA 515, no. 16 (22 April 1973), typewritten manuscript, GsD Archive, Harvard University (Sert Collection).

22 Utley, Picasso, 107. Despite such "blows," Picasso decided to extend his stay in Warsaw so as to be present for the ceremony scheduled in his and Paul Eluard's honour as the 1948 recipients of the "Croix de Commandeur avec l'Etoile de l'ordre Polonia Restituta." Syrkus, "Tel que je l'ai gardé dans la mémoire."

23 Two of the reference texts should at least be mentioned here: Louis Aragon, "Le réalisme a l'ordre du jour," Commune (1936): 20-32, repr. in idem., Ecrits sur l'art moderne (Paris: Flammarion, 1981); and Fernand Léger, Jean Gromaire, Le Corbusier, Jean Lurçat, Louis Aragon et.al., La querelle du réalisme (Paris: Éditions Cercle d'Art, 1987).

24 Some of the statements delivered at the 6th CIAM conference were summarized by Giedion in A Decade of New Architecture (Zurich: Girsberger, 1951), 30-40, as well as in his Architektur und Gemeinschaft. Tagebuch einer Entwicklung (Reinbek b. Hamburg: Rowohlt, 1956), 62-67, but there is no official documentation on the Bridgwater conference. For a more recent summary see Joan Ockman, Architecture Culture 1943-1968 (New York: Columbia Books of Architecture, Rizzoli, 1993), esp. 100-122. Regarding the East-West conflict within CiAm see also Eric Mumford, The CIAM Discourse on Urbanism, 1928-1960 (Cambridge, Mass.: MIT Press, 2000), 182-195

25 M. Hartland Thomas, letter to S. Giedion dated 24 June, 1946 (Giedion-Archive at gta Institute, ETH-Z). 
Stanislaus von Moos

26 Questionnaire prepared by the mars Group (1947; Giedion archive at the gta Institute, ETH-z). No evidence of these concerns is to be found either in the questionnaire prepared by the commission headed by Giedion himself or in the two final reports on the Bridgwater meeting prepared with Bergamo in mind ('Rapport A' and 'Rapport B'); see 7 CIAM Bergamo 1949. Documents (Nendeln: Kraus Reprint, 1979), n.p.. (For an incomplete summary of the minutes of the Bergamo meeting see also "VII CIAM. Il Settimo Congresso Internazionale di Architettura Moderna - Bergamo 22-31 luglio 1949”, Metron, no. 33-34 (1949): 48-72.

27 J. M. Richards, "Architectural Expression," lecture notes in preparation for ciam 6 in Bridgwater, 1947 (Giedion-Archive, gta Institute at ETH-Z). Interestingly, Richards's statements at CIAM 7 in Bergamo were considerably less provocative. See "Contemporary Architecture and the Common Man," in Giedion, ed., A Decade of New Architecture (Zurich: Girsberger, 1951), 33-34.

28 Author's translation from the German. Giedion, "J. M. Richards: 'The Castles on the Ground' (London: The Architectural Press, 1946)," Werk-Chronik, no. 4 (1947), 47-48.

29 Alfred Roth's ideas about postwar reconstruction are documented in a series of essays in the magazine Werk, published between 1943 and 1948; for Max Bill see primarily his Wiederaufbau. Dokumente über Zerstörungen, Planungen, Wiederaufbau (Erlenbach; Zurich: Verlag für Architektur AG, 1945). Roth and Bill are at the core of my forthcoming book entitled Erste Hilfe. Schweizer Architekten und die Welt seit 1940 (First Aid. Swiss Architects and the World since 1940).

30 Giedion, "The Castles on the Ground."

31 Statement for сіAм, dated 16 October, 1946 by Helena and Szymon Syrkus (preliminary translation into English by Stamo Papadaki; Giedion-Archive, gta Institute, ETH-z)

32 Ibid.. In a letter to Giedion dated 17 November 1947 Syrkus adds the following Ceterum Censeo: “. . . deshalb muss ciam das Wort modern fallen lassen - CONGRès internationaux D'Architecture sogiale ...” (Therefore ciam must drop the word modern - GONGRÈs internationauX D'ARGHITEGTURE SOGiale . . .).

33 "Was Deinem höchst interessanten Buch fehlt, ist gerade der rein marxistische Standpunkt, den Du nur gefühlsmässig anwendest, wenn man so sagen darf," Syrkus writes. Then she goes on urging Giedion "mal ganz vorurteilslos die Formulierung des historischen und dialektischen Materialismus" zu lesen, "die Stalin in wirklich vorbildlicher Weise in seiner kurzen Arbeit Historischer und dialektischer Materialismus, 1938, gibt. Wenn Du sie kennst, lies sie mal aufmerksam noch einmal, an den Städtebau denkend, und da wirst Du unseren Standpunkt richtig verstehen." Ibid. 
Ciam's Ghosts. Le Corbusier, Art, and World War it

34 Mumford, The CIAM Discourse, 182-183. See also Judt, Cold War, 206-209.

35 On Giedion and cultural politics under Stalin (and for Giedion's letter to Stalin regarding the jury decision in the Soviet Palace competition) see Martin Steinmann, CIAM: Internationale Kongresse für Neues Bauen: Dokumente 1928-1939 (Basel, Stuttgart: Birkhäuser, 1979), 124-129 as well as Daniel Weiss, "Eine Reise in die Sowjetunion, 1932," in Werner Oechslin and Gregor Harbusch, eds., Sigfried Giedion und die Fotografie. Bildinszenierungen der Moderne (Zurich: gta Verlag, 2010), 222-223.

36 Giedion, in Preface to the Polish edition of Space, Time and Architecture, quoted after "Vorwort für die polnische Ausgabe von Space, Time and Architecture,” Ms., Giedion-Archive, gta Institute, ETH-Z. Giedion's concept of the "ruling taste" is key to his vision of cultural politics as developed in Architecture, You and Me (Cambridge, Mass.: Harvard University Press, 1958), esp. 10-11, 2836, 68, 86-87 and passim, but it was first developed in Mechanization Takes Command (New York: Oxford University Press, 1948), 329-343.

37 Ciam 7, Bergamo 1949. Documents, 12-13 (French version).

38 Ibid., 11. For more on Truman and on Senator George Dondero's tirades against modern art see Saunders, The Cultural Cold War, 252-253. Sweeney, who had reported the Truman quote, was later to be the curator of the important travelling exhibition "Masterpieces of 20th Century Art," the biggest cultural enterprise ever sponsored by the cIA. For him, the propaganda character of modern art was a matter of fact, since that kind of art "could not have been created or allowed to be exhibited by such totalitarian regimes as Nazi Germany or present day Soviet Russia and her satellites." Ibid., 268.

39 Quoted after "VII CIAM. Il Settimo Congresso Internazionale di Architettura Moderna Bergamo 22-31 luglio 1949," Metron (1949), 59. Ironically, the façade of the "Palazzo Nuovo," allegedly designed by Scamozzi, was completed only in 1927; see Maria Luisa Scalvini, Gian Piero Calza, and Paola Finardi, Bergamo (Bari: Laterza, 1987), ills. 142, 143.

In the words of an Italian participant of the Bergamo meeting, Syrkus pleaded in favour of a "human urbanism" that, instead of imposing a predetermined life-form upon people "demands the creation of dwellings whose concept . . . derives from the will of those who have to inhabit them." See Nestorio Sacchi, I Congressi Internazionali di Architettura Moderna (Milan, 1998), 71. For a summary of the debates see Ockman, Architecture Culture. (Syrkus's talk "Art Belongs to the People" is on pages 120-122). Note that the Syrkus's patently modernist Kolo housing complex in Warsaw, then under construction, "slipped through the ideological net she was 
Stanislaus von Moos

herself now casting." David Crowley, "Europe Reconstructed, Europe Divided," in David Crowley and Jane Pavitt, eds., Cold War Modern: Design 1945-1970 (London: V\& A Publishing, 2008), 45 .

407 CIAM Bergamo. Documents, 9. The project in question may have been shown by Schmidt in an earlier session of the congress, though there are no corresponding minutes. The "house" referred to by Bill recalls a competition project Schmidt was to propose for a school in Niederholz, Switzerland, which also contains the sketch of a figurative mural to be placed in the recreation hall (1950). In his somewhat later competition project for a municipal hall in Potsdam, 1960, Schmidt would indeed envision a large mural to fill almost the entire surface of the main façade's base. See Ursula Suter, Hans Schmidt 1893-1972. Architekt in Basel, Moskau, Berlin-Ost (Zurich: gta, 1993), 283, 330; see also page 52.

417 CIAM Bergamo. Documents, 12.

42 "Architect, Painter and Sculptor," in Giedion, ed., A Decade of New Architecture, 30-40. See also his "Architects and Politics: An East-West Discussion," in Architecture, You and Me, 79-90.

43 "Wir können es nicht weiter verantworten, im ciam zu sitzen und zu sehen, wie man sich derart einseitig festlegt, wie dies durch Le Corbusier, Giedion und Roth etc. geschieht. Wir haben die Pflicht, entweder die ciam zu verlassen oder eine Diskussion zu eröffnen, die mehr als fällig ist." Letter by Hans Schmidt to Mart Stam, 10 July 1949, quoted after Suter, Hans Schmidt 18931972,50 .

44 Asger Jorn, "Homes for the People or Concrete Castles in the Air?" (1947), in Ruth Baumeister, ed., Fraternité Avant Tout. Asger forn's Writings on Art and Architecture, 1938-1958 (Rotterdam: 010 Publishers, 2011), 136-152; here 141. A few years later, the concept of "Spontaneity" would be invoked by Giedion, too, as key to what he called "Plastic Imagination" in building.

45 See in particular Asger Jorn, "New Painting New Architecture: Fernand Léger and Le Corbusier" (1938) or "Face to Face" (1944), in Fraternité Avant Tout, 35-38, 54-78.

46 "Homes for the People or Concrete Castles in the Air?," 137.

47 Ibid., 140.

48 Aldo van Eyck, undated Ms., (Giedion-Archive at gta Inmstitute, ETH-z); see also the re-worked version of this statement in Vincent Ligtelijn and Francis Strauven, eds.,, Aldo van Eyck, Collected Articles and Other Writings 1947-1998 (Amsterdam: SUN, 2008), 52. On van Eyck' and his statements made in Bridgwater see Strauven, Aldo van Eyck, The Shape of Relativity (Amsterdam: Architectura \& Natura, 1998), $117 \mathrm{ff}$. 


\section{Ciam's Ghosts. Le Corbusier, Art, and World War iI}

49 Italian members appear to have been particularly annoyed by Giedion's unwillingness to open up the discussion for new approaches to history in design; see Oechslin, “. . . auch ein Reisebericht - in die 'Geschichte,"' in Bruno Maurer and Werner Oechslin, eds., Der unendliche Raum der Architektur. Ulrich Stucky (1925-2009), Architekt, Planer, Forscher, Vermittle (Zurich: gta Verlag), 2009, 106-125. For Giedion's comments on the Unité d'habitation see his Architektur und Gemeinschaft, 100-105.

50 Manfredo Tafuri claimed that "Il Neorealismo italiano" is "the most noteworthy movement in our century" corresponding with an authentically "realist" sensibility. Tafuri, "Architettura e Realismo," in Vittorio Magnago Lampugnani, ed., L'avventura delle idee nell'architettura 1750-1980 (Berlin; Milan: Internationale Bauausstellung Berlin; Triennale di Milano, 1985), 123-136; here 123. For a more recent appreciation of Italian Neo-realism see Jane Pavitt, "Design and the Democratic Ideal," in Crowley and Pavitt, Cold War Modern, 72-93.

51 The best documentation on Team X is by Dirk van den Heuvel and Max Risselada, eds., Team X 1953-81. In Search of a Utopia of the Present (Rotterdam: NAi Publishers, 2006).

52 William Curtis, Le Corbusier. Ideas and Forms (Oxford: Phaidon, 1986), 198. I have tried to explore the political and ideological context of Chandigarh's foundation in "The Politics of the Open Hand: Notes on Le Corbusier and Nehru at Chandigarh," in Russell Walden, ed., The Open Hand. Essays on Le Corbusier (Cambridge, Mass.: MIT Press, 1977), 412-457, but the present chapter is primarily on the symbolism of the monument that goes by that name.

53 "Ich möchte verschenken und austeilen, bis die Weisen unter den Menschen wieder einmal ihrer Torheit und die Armen wieder einmal ihres Reichtums froh geworden sind." Friedrich Nietzsche, Also Sprach Zarathustra. Ein Buch für Alle und Keinen (1975 edition), 87 (author's translation). On the title page of his copy of Ainsi parla Zarathustra Le Corbusier indicated the time and place of his first reading of the book (Paris, 1909) and the passages most directly relevant for the symbolism of the open hand.

For a brief genealogy of the motif's form and symbolism see my Le Corbusier. Elements of a Synthesis, 286-290, but the most acute interpretation is by Marie-Jeanne Dumont, "Die offene Hand. Vom politischen Symbol zur Signatur des Künstlers," in Olivier Quincalbre and Frédéric Migayrou, ed., Le Corbusier. Die menschlichen Masse (Paris; Zurich: Centre Pompidou; Scheidegger \& Spiess, 2015), 135-141.

54 On the political circumstances and ideological implications of Chandigarh's foundation see primarily Vikramaditya Prakash, Chandigarh's Le Corbusier. The Struggle for Modernity in Postcolonial 
Stanislaus von Moos

India (Seattle, WA: The University of Washington, 2002) and Ravi Kalia, Chandigarh: The Making of an Indian City (New Delhi: Oxford University Press, 2002). For a new assessment considering also the role of international organizations see now Tom Avermate and Maristella Casciato, eds., Chandigarh Casablanca. A Report on Modernization (Montreal; Zurich: CCA; Park Books, 2014), 54-87.

55 See Avermate and Casciato, Chandigarh Casablanca, 54-57 for the basic information. Already in 1946, thus before India even existed as an independent nation, Mahatma Gandhi and his designated successor, Pandit Nehru, had instructed the Indian delegates at the first General Assembly of the United Nations scheduled to be held in London, "to stay clear of rival power blocs and try to ease the tensions that such blocs generated." Mark Mazower, No Enchanted Place. The End of Empire and the Ideological Origins of the United Nations (Princeton, Oxford: Princeton University Press, 2009), 177.

The drawing by Le Corbusier mentioned before is from the Carnet Nivola, 211; FLC, Paris). In the 1980s, an international financing campaign ultimately allowed a version of the "Open Hand" to be erected posthumously in the intended location.

56 Le Corbusier, Le Modulor 2, (Boulogne-sur-Seine: Éditions de l'Architecture d'aujourd'hui, 1959), 269-274.

57 A photograph of the "Marseillaise," including also a view of the Arc de Triomphe and the Eiffel Tower, had already appeared on the cover of Logis et loisirs. 5ième Congrès CIAM Paris 1937 (Boulogne-sur-Seine: Éditions de l'Architecture d'aujourd'hui, 1937); and a drawing representing the same "pastiche" appears on the cover of Le Corbusier, Destin de Paris (Paris: Collection Préludes, 1941).

58 Maurice Thorez, "Discours de Maurice Thorez, 17 avril 1936." The relevance of this speech in connection with the monument as well as the respective bibliography was indicated to me by Jean-Louis Cohen.

59 Francis J. Murphy, “La Main Tendue': Prélude to Christian-Marxist Dialogue in France, 19361939." In Catholic Historical Review, vol. 60, no. 2 (July 1974): 255-270.

60 Following the "caprice of events" (Le Corbusier), after World War II "Rockefeller" (via the Museum of Modern Art in New York) inquired about the possibility of building the monument as a memorial to the GI's fallen in France during the war. See Le Corbusier textes et planches (Paris: Vincent Fréal \& Cie., 1960), 135.

61 Amédée Ozenfant, Foundations of Modern Art (New York: John Rodker, 1931), xi-xii. Originally 


\section{Ciam's Ghosts. Le Corbusier, Art, and World War ii}

published in idem., Art (Paris: Jean Baudry, 1929). See also the earlier essay by Amédée Ozenfant and Charles-Edouard Jeanneret, "De la peinture des cavernes à la peinture d'aujourd'hui," L'Esprit Nouveau, no. 15 (1922): 1795-802.

62 Georges Bataille, La Peinture préhistorique. Lascaux et la naissance de l'art (Geneva: Skira, 1955). See also idem., The Cradle of Humanity. Prehistoric Art and Culture (New York: Zone Books, 2009); Giedion, The Eternal Present I: The Beginnings of Art (New York: Bollingen Foundation, 1962), 93124.

63 Adolf Muschg, "Ueber die Unzulänglichkeit bedeutender Architektur," in idem., Fremdkörper. Erzählungen (Zurich: Die Arche, 1968), 71-108; here 103. Werner Bischof's famous "Report on India" had been commissioned by and published in LIFE Magazine in 1951, the year of Le Corbusier's conversation referred-to above; see Peter Edwin Erismann, "Indien sehen Looking at India. Schweizer Fotografinnen und Fotografen," in idem., ed., Indien Sehen. Kunst, Fotografie, Literatur (Baden; Bern: Verlag Lars Müller; Schweizeriscdhe Landesbibliothek, 1997), 91-112.

64 "Nuclear Sublime," a variation on Peter B. Hales, "The Atomic Sublime," American Studies (1991): 4-31.

65 If Winfried Georg Sebald is correct, conditions of crime, catastrophy and mourning appear to be particularly conducive to this type of blindness. See Sebald, "Air War and Literature," in his The Natural History of Destruction, 1999. For a discussion of "ruin" as a condition of architecture in general, and of "ruins" as a reality architects could not ignore in the aftermath of World War II, see my "Ruin Count. Le Corbusier and European Reconstruction." An inspiring alternative view is offered by Kurt W. Forster, "Die Ruine als Nachklang, Vorbild oder Zukunftsbotin," in Claudia Blümle and Jan Lazardzig, eds., Ruinierte Oeffentlichkeit. Zur Politik von Theater, Architektur und Kunst in den 1950iger Fahren (Zurich, Berlin: Diaphanes, 2012), 182-206.

66 Anthony Vidler, "Air War and Architecture," in Julia Hell and Andreas Schönle, eds., Ruins of Modernity (Durham: Duke University Press, 2010), 29-40.

67 Bombed Churches as War Memorials (Cheam, Surrey; London: The Architectural Press, 1945). T.S. Eliot as well as John M. Keynes were among the signers of the petition. See Christopher Woodward, In Ruins (London: Vintage, 2002), 212, and Marc Treib, "Remembering Ruins, Ruins Remembering," in idem., ed., Spatial Recall. Memory in Architecture and Landscape (New York, London: Routledge, 2009), 194-217, 216.

68 The drawing must have been prepared as an illustration to Kahn's essay on "Monumentality," 
Stanislaus von Moos

in Paul Zucker, ed., New Architecture and City Planning (New York: Philosophical Library, 1944), 577-588, but was not used on that occasion. A photograph of the drawing survives in the Kahn collection at the Museum of Modern Art, New York.

69 The literature on Saint-Dié does not need to be reported here. The most recent discussion is by Mary McLeod, “Saint-Dié: ‘A Modern Space Conception’ for Postwar Reconstruction,” in Cohen, Le Corbusier. An Atlas of Modern Landscapes, 193-199.

70 See Cohen, France ou Allemagne? Un livre inédit de Le Corbusier (Paris: Édition de la Maison des sciences de l'homme, 2009). Le Corbusier owned many picture postcards commemorating the bombardment.

71 Giuliano Gresleri and Glauco Gresleri, Le Corbusier, Il programma liturgico (Bologna: Editrice Compositori, 2001), 70.

72 In a text fragment dated April 4, 1946, Le Corbusier formulates his radical objection against reconstruction as a way of preserving monuments. Gresleri and Gresleri, Le Corbusier. Il progetto liturgico, 221-222.

73 Reyner Banham, "The New Brutalism," Architectural Review (December 1955): 354-361. The echo of "The New Empiricism. Sweden's Latest Style," The Architectural Reviewe, no. 6 (1947): 109-204, can hardly be overstated. See also Eric de Maré, "The Antecedents and Origins of Sweden's Latest Style," The Architectural Review (1948): 9-12. The following discussion, however, is based on Banham's The New Brutalism. Ethic or Aesthetic? (London: The Architectural Press, 1970).

74 Banham, The New Brutalism in Architecture, 11.

75 Ibid., 13.

76 See Anders Aman, Architecture and Ideology in Eastern Europe during the Stalin Era. An Aspect of Cold War History (New York; Cambridge, Mass.: The Architectural History Foundation; MIT Press, 1992), 211-219 for a good summary of De-Stalinization in the UssR.

77 J. M. Richards, The Castles on the Ground (London: The Architectural Press, 1946).

78 Banham, The Nerw Brutalism, 12. Measured up against that reality, the "fashionably morbid school of landscape/townscape painting" à la Graham Sutherland and its "mood of elegant dispair" was nothing less than "A blank betrayal of everything that Modern Architecture was supposed to stand for," if not, indeed, an "act of treachery"; ibid., 13.

79 Alex Potts, "New Brutalism and Pop," in Mark Crinson and Claire Zimmerman, ed., Neo-avantgarde and Postmodern. Postwar Architecture in Britain and Beyond (New Haven: Yale University Press, 2010), 29-52, esp. 37. 


\section{Ciam's Ghosts. Le Corbusier, Art, and World War ii}

80 Van den Heuvel and Risselada, eds., Alison and Peter Smithson: From the House of the Future to a House of Today (Rotterdam: 010 Publishers, 2004), 79-95, 79-95; see also Colomina, "Unbreathed Air 1956," in ibid., 31-49.

81 Ibid., 14.

82 For Banham's own retrospective view on the British quarrels on the "Picturesque" see his "Revenge of the Picturesque: English Architectural Polemics, 1945-1965," in John Summerson, ed., Concerning Architecture: Essays on Architectural Writing Presented to Nikolaus Pevsner (London: Penguin, 1968), 265-730.

83 Banham, The New Brutalism, 16, but see also Banham's "The New Brutalism."

84 Banham, The New Brutalism, 16. For the architect's own comments on the "malfaçons," see Le Corbusier, Euvre complète 1946-1942, 189-191 and the captions on pages 214 and 218. Some implications of Le Corbusier's cult of "Non Finito" are discussed in my "Ruins in Reverse.' Notes on Photography and the Architectural 'Non Finito," in von Moos, ed., Ernst Scheidegger: Chandigarh 1956 (Zurich: Scheidegger \& Spiess, 2009), 45-66.

85 Vincent Scully, "Le Corbusier 1922-1965," quoted after Neil Levine, ed., Vincent Scully: Modern Architecture and Other Essays (Princeton, NJ: Princeton University Press, 2003), 246.

86 See Alison and Peter Smithson, "Human Associations," in Ordinariness and Light (London: Faber and Faber, 1970), 44-61; and van den Heuvel and Risselada, eds., Alison and Peter Smithson, 61-78.

87 What Le Corbusier had in mind when he referred to Marseilles as a "battlefield" was the battle against the unionized architects in France and their organizations, which were determined to stop the project (see von Moos, Le Corbusier: Elements of a Synthesis, 156; Monnier, Le Corbusier: Les Unités d'habitation, 46-47, 60-62, passim). The Smithsons had visited the Unité's construction site before; see Alison and Peter Smithson, Without Rhetoric: An Architectural Aesthetic (London: Latimer New Dimensions, 1973), 4, passim. For a recent discussion of the project see Martino Stierli, "Taking on Mies: Mimicry and Parody of Modernism in the Architecture of Alison and Peter Smithson and Venturi/Scott Brown," in Mark Crimson and Claire Zimmerman, eds., Neo-avantgarde and Postmodern: Postwar Architecture in Britain and Beyond (New Haven, CN: Yale University Press, 2010), 151-174.

88 See Wikipedia, Bombardements de Marseille, accessed March 1, 2015. In 1940 the German Luftwaffe had already bombed the city; furthermore, under the German occupation its core, the Vieux port, was razed and rebuilt entirely. 
Stanislaus von Moos

89 Le Corbusier, When the Cathedrals Were White (New York: Reynal and Hitchcock, 1947; rev. ed. McGraw Hill, 1964), xl. The book was originally published as Quand les cathédrales étaient blanches (Paris: Éditions Plon, 1937).

90 Crowley, "Europe Reconstructed, Europe Divided," 43-71, here 55.

91 Detlef Mertins, Modernity Unbound (London: Architectural Association, 2011), 180ff. Some of the ideas underlying the following lines have been developed in greater detail elsewhere; see "Die Welt als Skulptur: Zur Aktualität der 'Synthese der Künste,” in Regula Krähenbühl, ed., Avantgarden im Fokus der Kunstkritik: Eine Hommage an Carola Giedion-Welcker (1893-1979) (Zurich: SIK/ISEA, 2011), 17-32.

92 Carola Giedion-Welcker, Contemporary Sculpture: An Evolution in Volume and Space (New York: Wittenborn, 1960), 231-233.

93 Idem., "Die magische Dingwelt der Pittura metafisica," in Regula Krähenbühl, ed., Carola Giedion-Welcker, Schriften 1926-1971: Stationen zu einem Weltbild (Cologne: DuMont Schauberg, 1973), 131-136. The essay was first presented as a lecture in 1950.

94 "Nées dans la fureur, elles sentent encore la poudre," Monnier writes on Le Corbusier's Unités in Le Corbusier: Les Unités d'habitation, 186.

95 "Mariant souvent sans lien apparent comme dans la vie / Les sons les gestes les couleurs les bruits / La musique la danse l'acrobatie la poésie la peinture / Les choeurs les actions les décors multiples" (Guillaume Apollinaire). 